\title{
ANNEXATION AND THE MID-SIZE METROPOLIS: NEW INSIGHTS IN THE AGE OF MOBILE CAPITAL
}

\author{
Christopher J. Tyson*
}

\begin{abstract}
Metropolitan regions are led by their central cities. They want and need to grow, but the suburban sprawl and municipal fragmentation that growth produces stand in the way. Fragmentation handicaps the central city's ability to effectively coordinate responses to regional issues. Mid-size regions are especially vulnerable to the effects of fragmentation, as they face unique economic development and sociological challenges. First, mid-size regions lack many of the assets necessary to compete globally for mobile capital. Second, social inequality plays out differently in mid-size regions, which are spatially constrained and have pervasive low-density land use patterns. Municipal boundaries reflect these divisions and determine who gets to participate in the redistribution of the community's resources. Of the many urban policy options available for addressing these challenges, annexation is both the most potent and the most controversial. This article explores how the growth ambitions of mid-size central cities are affected by their respective state annexation regimes. The article examines annexation battles in Mississippi, Tennessee, and North Carolina to observe how different annexation regimes help or hinder midsize central cities. Ultimately the article finds that mid-size central cities need annexation regimes that help them to address social inequality while maximizing their economic competitiveness.
\end{abstract}

\footnotetext{
* Assistant Professor of Law at the Paul M. Hebert Law Center at Louisiana State University; B.A., Howard University; M.P.P., Harvard Kennedy School; J.D., Georgetown University Law Center. I would like to thank Brittan Bush, Barry Edwards, Joseph Manning, Riean Norman, and Hansford Wogan for excellent research assistance. I would also like to thank the participants of the 2011 John Mercer Langston Writing Workshop, the 2011 Southeastern Association of Law Schools New Scholars Workshop, Mitch Crusto, Charlton Copeland, Ray Diamond, Ed Richards, Christopher Odinet, and Judith Wegner for extremely useful suggestions and for reading previous drafts of this article.
} 
U N I V E R S I T Y O F P I T T S B U R G H L A W R E V I E W

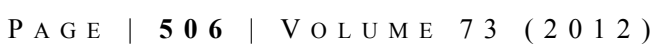

\section{Table of Contents}

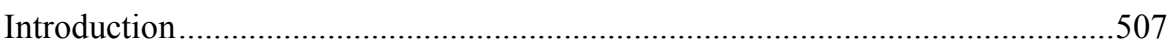

Part I: $\quad$ A Brief Overview of Municipal Annexation....................................510

Part II: The Mid-Size Metropolis and the Annexation Imperative....................520

A. Metropolitanization and Defining the Mid-Size Metropolis ...............521

B. The Mid-Size Metropolis, Economic Development and Mobile

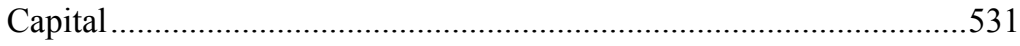

Part III: Annexation in Context: Approaches and Solutions ...........................541

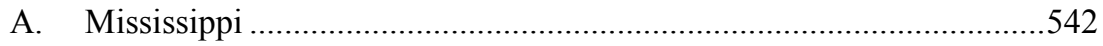

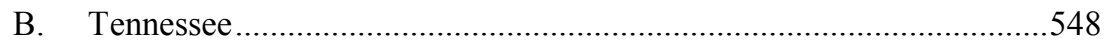

C. North Carolina ..............................................................................55

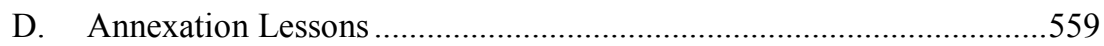

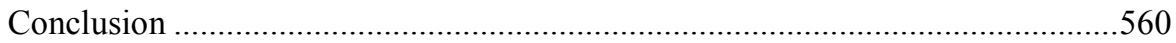




\section{INTRODUCTION}

Every city wants to be larger. Not just for the sake of being larger, but because being larger almost always means more people, better employment opportunities, better lifestyle options, and higher property values. Standing in the way of municipal land growth, however, is urban sprawl. ${ }^{1}$ While sprawl relates to the territorial expansion of the city's identity, it often occurs outside of a municipality's borders. Sprawl outside of a municipality's borders results both in the development of unincorporated enclaves within the metropolitan region, as well as the incorporation of new municipalities on the central city's fringe. As these separate and autonomous local government units grow in number, they limit the central city's growth options. The metropolitan region becomes fragmented, and municipal fragmentation can foster provincialism within the various jurisdictions. ${ }^{2}$

Provincialism often thwarts regional cooperation, and a lack of cooperation can have grave implications for economic development and social relations throughout a metropolitan region. ${ }^{3}$ Metropolitan regions compete with each other for new businesses and residents. ${ }^{4}$ They all have specific land use, service delivery, and resource disparities, however, the effects of which can imperil economic development for the entire region. These disparities typically correspond with race and class dynamics in a manner that intensifies the geographic distribution of privilege and disadvantage. Local governments play a key role in marshaling regional assets to respond to competitive realities, yet increased fragmentation makes coordinating response efforts difficult. The more of the region's land area

\footnotetext{
${ }^{1}$ One of the many definitions for urban sprawl provides that sprawl occurs when metropolitan areas consume land for urbanization at a faster rate than they add population. See, e.g., William Fulton ET al., Brookings Inst. Ctr. on Urban \& Metro. Policy, Who Sprawls Most? How Growth PATterns DifFer ACRoss the U.S. 2-4 (2001). Sprawl has also been described as "unplanned, uncontrolled, and uncoordinated single use development that does not provide for a functional mix of uses and/or is not functionally related to surrounding land uses and which variously appears as lowdensity, ribbon or strip, scattered, leapfrog, or isolated development." John I. Carruthers \& Gudmundur F. Ulfarsson, Fragmentation and Sprawl: Evidence from Interregional Analysis, 33 GROWTH \& Change 312, 314 (2002) (quoting Arthur C. Nelson et al., Growth Management: Principles AND PRACTICES (1995)).

${ }^{2}$ See, e.g., Richard Briffault, Our Localism: Part I-The Structure of Local Government Law, 90 Colum. L. Rev. 1, 77-81 (1990); Sheryll D. Cashin, Localism, Self-Interest and the Tyranny of the Favored Quarter: Addressing the Barriers to the New Regionalism, 88 GEO. L.J. 1985, 2014-15 (2000) (discussing the consequences of municipal fragmentation within a metropolitan region).

${ }^{3}$ See infra notes 110,118 and accompanying text.

${ }^{4}$ See infra note 139 and accompanying text.
} 
the central city controls, the better its chances of maximizing economic development throughout the region. ${ }^{5}$

Mid-size regions are especially vulnerable to the effects of sprawl and intraregional municipal fragmentation. They face unique governance and economic development obstacles that are often underestimated or outright ignored in broader considerations of urban policy or local government law. ${ }^{6}$ Unlike large regions, most mid-size regions lack the critical mass of competitive credentials necessary for maximizing their economic development potential. ${ }^{7}$ This is further complicated by the realities of increasing global, inter-urban competition for mobile capital. ${ }^{8}$

Geoeconomic forces are transforming the nature of economic development and the capital attraction strategies of metropolitan regions. ${ }^{9}$ Global inter-urban competition for mobile capital is a defining feature of municipal governance and a relatively high stakes game for mid-size regions. ${ }^{10}$ As regional anchors, mid-size central cities set the tone for their regions' relative economic competitiveness. They must therefore be able to exercise leadership in establishing the preconditions for economic viability and growth. The proliferation of multiple local government units within a region disperses decision-making power over a range of entities and interests, complicating regional decision making.

In addition to the impact on economic development efforts, in every metropolitan region there are sociological dimensions to the meaning and management of municipal boundaries. Boundaries are powerful social constructions mapped onto existing landscapes and given the force of law. They

${ }^{5}$ See infra note 121 and accompanying text.

${ }^{6}$ See infra note 87 and accompanying text.

${ }^{7} I d$.

${ }^{8}$ Mobile capital refers to the ability of corporations, firms, investors, and other conglomerations of private funds to move across national and regional borders in pursuit of higher investment returns. The problem of mobile capital is borne out by the phenomenon of capital flight, and the law and politics of local government is constituted by the ever-evolving relationship between cities and business. As local governments and metropolitan regions position themselves to compete for mobile capital, they participate in a global competition that pits metropolitan region against metropolitan region. See, e.g., Richard Briffault, Our Localism Part II-Localism and Legal Theory, 90 CoLUM. L. REV. 346, 421-22 (1990) (discussing the relative mobility of capital in shaping inter-local competition); Richard C. Schragger, Mobile Capital, Local Economic Regulation, and the Democratic City, 123 HARV. L. Rev. 482, 487-88 (2009).

${ }^{9}$ See infra note 126 and accompanying text.

${ }^{10}$ See, e.g., Schragger, supra note 8, at 488-92. 
determine who gets to participate in the redistribution of the community's resources. Race and class stratification is in many ways a result of the formation and reformation of municipal boundaries. The large metropolitan region is often the default frame for understanding these dynamics. This stratification takes on different dimensions, however, in mid-size regions, where different race and class groups exist in relatively spatially constrained, yet low-density, land use patterns. ${ }^{11}$

Of the many urban policy options available for addressing these challenges, annexation is one of the most controversial. Annexation, the process through which municipalities extend their boundaries to envelop outlying unincorporated areas, is the most frequently utilized method for boundary adjustment and municipal land area growth. ${ }^{12}$ Despite its guiding role in urban policy, annexation is seldom viewed as an essential component of a comprehensive metropolitan economic development strategy. ${ }^{13}$ Municipalities often pursue annexation on an ad hoc basis for development activity in unincorporated areas that will enhance their tax base, such as building office parks and shopping centers. Annexation activity originating out of these situations is different from its inclusion in a broader, comprehensive economic development strategy. ${ }^{14}$

A state's annexation law is an important and often under-appreciated expression of its land use policy. While there are many drivers of economic competitiveness and social stratification, land use plays an important role. In the Brookings Institute Report, Annexation and the Fiscal State of Cities, David Rusk quantifies the relationship between boundary elasticity and municipal economic well-being. ${ }^{15}$ According to Rusk, state annexation regimes that facilitate maximum

${ }^{11}$ See infra note 107 and accompanying text.

${ }^{12}$ See infra note 65.

13 While some texts on economic development reference municipal boundaries, none explicitly incorporates boundary expansion as part of a broader economic development strategy. See, e.g., WASH. Research Council, Economic Development: Growth Management's Missing LinK (2002); Corp. For Enter. Dev., Strategic Planning for EConomic Development: Moving Beyond the Overall EConomic DeVelopment Program (1999).

${ }^{14}$ Annexation is a broad issue with implications for a range of local government units, related issues, and core functions. See, e.g., Mary M. Edwards, Understanding the Complexities of Annexation, 23 J. PlanNING Literature 119 (2008). While this author is aware of the many dimensions and considerations associated with municipal annexation, this article will focus on the relationship between a state's annexation regime and the manner in which it impacts the economic development challenges faced by mid-size metropolitan regions.

${ }^{15}$ David Rusk, Brookings Inst. Metro. Policy Program, AnneXation and the Fiscal Fate of CITIES (2006). 
U N I V E R S I T Y O F P I T T S B U R G H L A W R E V I E W

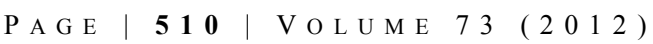

central city boundary elasticity are likely to enhance the fiscal position and, by extension, economic competitiveness of their metropolitan regions. This holds specific relevance for the central cities of mid-size metropolitan regions for which the consequences of fragmentation and sprawl more acutely affect economic development and social relations.

The fate of mid-size metropolitan regions is tied in large measure to their ability to reconcile intra-regional municipal fragmentation with increasing global inter-urban competition for mobile capital. Annexation battles in several states illustrate this well. While North Carolina's annexation laws have recently undergone substantial change, for more than fifty years the state has had the nation's most pro-central city annexation regime. Mississippi, on the other hand, has seen its largest central city anchor, Jackson, choked by sprawl and stifled by its relatively thin annexation regime. North Carolina and Mississippi represent opposite ends of the annexation policy spectrum. Neither is a perfect model. Both show how, if incorporated into a broader metropolitan economic development plan, annexation can be a critical tool in boosting the economic competitiveness of midsize metropolitan regions.

Part I of this article reviews the historical development and the sociopolitical impact of annexation policy. Part II defines and contextualizes the mid-size metropolis for the purpose of illuminating the economic development and governance challenges at the core of its identity. Part III explores how the growth ambitions of Mississippi's, Tennessee's, and North Carolina's mid-size central cities are affected by their respective annexation regimes. The article concludes by exploring policy innovations for enhancing the potency of annexation regimes in states with predominately mid-size metropolitan regions.

\section{Part I: A Brief OVerview of Municipal Annexation}

Scholars in several disciplines have long explored the politics, sociology, and law of municipal boundary formation and reformation. ${ }^{16}$ Urban historian Kenneth Jackson opined: "[W]ithout exception, the adjustment of local boundaries has been the dominant method of population growth in every American city of

\footnotetext{
${ }^{16}$ See, e.g., Michelle Wilde Anderson, Mapped Out of Local Democracy, 62 Stan. L. Rev. 931 (2010); Amanda K. Baumle et al., Strategic Annexation Under the Voting Rights Act: Racial Dimensions of Annexation Practices, 24 HaRV. Blackletter L.J. 81 (2008); Elizabeth R. Connolly, Bargain Basement Annexation: How Municipalities Subvert the Intent of North Carolina Annexation Laws, 29 N.C. CENT. L.J. 77 (2006); Edwards, supra note 14; Clayton P. Gillette, Voting with Your Hands: Direct Democracy in Annexation, 78 S. CAL. L. REV. 835 (2005); Rex L. Facer, Annexation Activity and State Law in the United States, 41 UrB. AfFAIRS ReV. 697 (2006).
} 
consequence."17 Annexation regimes are a significant area of state and local government law affecting the ability of cities to respond to population shifts and development demands within a metropolitan region. They are also powerful tools in the quest to control and limit sprawl in America's metropolitan regions. Annexation laws are not controlled by the federal government, however, making the development and application of a broad national standard impossible. ${ }^{18}$

State annexation policy has evolved considerably over the past century. Forcible annexation was the predominant doctrine in the states during the nineteenth century. It ensured that no small territory would be allowed to retard the development of the metropolitan community. ${ }^{19}$ As suburban development grew, state legislatures began redefining the legal concept of a city to include suburbs, liberalizing municipal incorporation laws, and placing new restrictions on the abilities of central cities to expand. ${ }^{20}$

The rise of localism coincided with the rise of city power. ${ }^{21}$ Many contemporary notions of the city and city power have their roots in the causes of the Progressive Era, particularly with regard to municipal government reform. ${ }^{22}$ Around the turn of the twentieth century, both policy makers and jurists alike were concerned that with the national government and economy rapidly growing in size,

${ }^{17}$ See Kenneth Jackson, Crabgrass Frontier: The Suburbanization of the United States 140 (1985).

${ }^{18}$ While annexation law is the province of state government, certain states must have annexations precleared by the United States Justice Department under Section 5 of the Voting Rights Act of 1965. See Voting Rights Act of 1965, 42 U.S.C. § 1973c (2006).

${ }^{19}$ See JACKSON, supra note 17, at 147.

${ }^{20}$ See Briffault, supra note 8, at 357-64 (discussing the social and demographic changes that influenced the evolution of the legal classification of suburbs and the manner in which it has limited the ability of metropolitan region central cities to grow).

${ }^{21}$ For a definition of "localism," see infra note 123 and accompanying text.

${ }^{22}$ The Progressive Era in the United States was a period of reform that flourished from the 1890 s to the 1920s. While the era is known for its innovative approaches to government and urban policy, the Progressive Era was also marked by the growth of racism and colonialism. Progressives drew support primarily from the middle class, and supporters included many lawyers, teachers, physicians, ministers, and businesspeople. Progressives sought to keep corruption out of politics and many Progressives successfully exposed and undercut political machines and bosses. Their governmental reform efforts were focused on waste and the delivery of public services by city and state governments. Their efforts led to the development of a more structured system and more localized power. Changes were made to local government to make legal processes, market transactions, bureaucratic administration, and democracy easier to manage, thus giving birth to municipal administration. See, e.g., STEVEN J. DINER, A Very Different Age: Americans of the Progressive ERA (1998). 
scope, and sophistication, the specter of unregulated and unfettered local power threatened to create a disastrous maze of conflicting and contradictory local laws, customs, and regulations that would ultimately frustrate national objectives. ${ }^{23}$

Conflicts over state and local power were settled in Hunter v. City of Pittsburgh. ${ }^{24}$ In Hunter, the Supreme Court effectively settled the notion that there is any federally protected right to local self-government and solidified the status of cities as merely creatures of state law. ${ }^{25}$ The case and the developments in local

${ }^{23}$ See Gerald Frug, The City as a Legal Concept, 93 HARV. L. Rev. 1059, 1066-67 (1980).

${ }^{24} 207$ U.S. 161 (1907).

${ }^{25}$ The lack of any substantive right to local self-government is the foundational principal of local government law and is essential to understanding the state's role in shaping boundary formation and reformation policy. See id. at 178-79 ("Municipal corporations are political subdivisions of the State, created as convenient agencies for exercising such of the governmental powers of the State as may be entrusted to them. For the purpose of executing these powers properly and efficiently they usually are given the power to acquire, hold, and manage personal and real property. The number, nature and duration of the powers conferred upon these corporations and the territory over which they shall be exercised rests in the absolute discretion of the State. Neither their charters, nor any law conferring governmental powers, or vesting in them property to be used for governmental purposes, or authorizing them to hold or manage such property, or exempting them from taxation upon it, constitutes a contract with the State within the meaning of the Federal Constitution. The State, therefore, at its pleasure may modify or withdraw all such powers, may take without compensation such property, hold it itself, or vest it in other agencies, expand or contract the territorial area, unite the whole or a part of it with another municipality, repeal the charter and destroy the corporation. All this may be done, conditionally or unconditionally, with or without the consent of the citizens, or even against their protest."); see also Briffault, supra note 2, at 7-8 ("As a matter of conventional legal theory, the states enjoy complete hegemony over local governments. Under both federal and state constitutional law, local governments have no rights against their states. Localities may not assert the contracts clause, the equal protection clause or the privileges and immunities clause against their state governments. Nor do the residents of local governments have any inherent right to local self-government: local residents may not assert a constitutional claim to belong to a particular local government or to have any local government at all. The formal legal status of a local government in relation to its state is summarized by the three concepts of 'creature,' 'delegate' and 'agent.' The local government is a creature of the state. It exists only by an act of the state, and the state, as creator, has plenary power to alter, expand, contract or abolish at will any or all local units. The local government is a delegate of the state, possessing only those powers the state has chosen to confer upon it. Absent any specific limitation in the state constitution, the state can amend, abridge or retract any power it has delegated, much as it can impose new duties or take away old privileges. The local government is an agent of the state, exercising limited powers at the local level on behalf of the state. A local government is like a state administrative agency, serving the state in its narrow area of expertise, but instead of being functional specialists, localities are given jurisdictions primarily by territory, although certain local units are specialized by function as well as territory.") (internal citations and formatting omitted). 
government law that followed marked a considerable shift in the legal conception of both the city and the suburb in American urban policy. ${ }^{26}$

Over time, many states have moved away from annexation regimes that expand central city power and toward systems that subject central cities to restraints and conditions that safeguard the prerogatives of suburban jurisdictions. Some states have effectively foreclosed the option for their municipalities to expand their boundaries. For instance, throughout New England, New York, New Jersey, and Pennsylvania, all territory is divided among a myriad of cities, villages, boroughs, towns, or townships, and there is no unincorporated land. ${ }^{27}$ Other states have annexation laws that are seldom used because the relative strength of their unincorporated townships and other areas make it difficult for central cities to annex them. ${ }^{28}$

The methods for annexation commonly found in state law can be divided into five categories: popular determination, municipal action (ordinance or resolution), legislative determination, quasi-legislative determination (regional or statewide boundary review commissions), and judicial determination. States with popular determination allow the affected members of the electorate, property owners, area residents, or some combination thereof to determine if a boundary change will be enacted. States with municipal determination allow the municipality to unilaterally extend its boundaries. Most states combine several of these methods to provide both cities and residents with various alternatives and a range of options to choose from. ${ }^{29}$ The result is a great deal of variation across the states regarding municipal annexation.

${ }^{26}$ See, e.g., Kenneth Stahl, The Suburb as a Legal Concept: The Problem of Organization and the Fate of Municipalities in American Law, 29 CARDOZO L. REV. 1193 (2008) (discussing the historical relationship between cities and the socioeconomic and political factors fueling the development of the twentieth-century suburb); Wayne Batchis, Enabling Urban Sprawl: Revisiting the Supreme Court's Seminal Zoning Decision Euclid v. Ambler in the 21st Century, 17 VA. J. Soc. POL'Y \& L. 373 (2010) (discussing Euclid v. Ambler Realty, 272 U.S. 365 (1926), and its impact on the development of suburban sprawl and the historical nexus between suburban development and center city decline).

${ }^{27}$ See RUSK, supra note 15 , at 7.

${ }^{28}$ For the relevant annexation regimes within each state under Rusk's classification, see 65 ILL. COMP. Stat. 5/7-1-1 (2011); IND. CodE § 36-4-3 (2011); IOWA CodE § 368.7 (2011); Kan. STAT. ANN. § 12519 (2011); Mo. Rev. Stat. $§ 71.014$ (2011); Neb. Rev. StAT. § 14-117 (2011); N.D. CENT. Code $\S$ 40-51.2 (2011); S.D. CODIFIED LAWS § 9-4-1 (2011); WIS. STAT. § 66.0217 (2011).

${ }^{29}$ See, e.g., Frank D. Sengstock, Annexation: A Solution to the Metropolitan Area Problem (Univ. of Mich. Law Sch. ed. 1960); Richard Briffault \& LaURie Reynolds, Cases AND MATERIALS On StATE AND LOCAL GOVERNMENT LAW 211 (7th ed. 2009). 


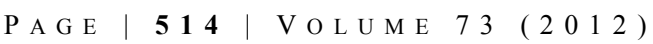

Many states attach conditions to the annexation process that can severely inhibit a municipality's ability to expand. Thirty-four states allow the annexation process to be initiated by a petition of property owners in the areas to be annexed. ${ }^{30}$ In nine of these states, annexation can be initiated only by property owner petition, a limitation that puts central city expansion in the hands of suburban developers and residents. ${ }^{31}$ Fourteen states require the approval of the affected voters. ${ }^{32}$ Eleven states require that the affected county government must approve any municipal annexation. ${ }^{33}$ Twenty-nine states provide for an election in the area to be annexed at some point in the annexation process. ${ }^{34}$ Annexations that require the approval of a majority vote of the residents or property owners in the area proposed for annexation complicate municipal expansion plans by placing all power over boundary change in the hands of those of who may have deliberately fled the central city and are therefore likely opposed to its expansion.

Involuntary annexation provisions allow municipalities to unilaterally expand their boundaries. Affected landowners often have little or no right to dissent as long as the annexing body complies with the strict geographical and developmental criteria and procedures set forth in the statutory requirements. ${ }^{35}$ States that allow involuntary annexation include Indiana, ${ }^{36}$ Kansas, $^{37}$ Kentucky, $^{38}$ Nebraska, ${ }^{39}$ Tennessee, ${ }^{40}$ and Texas. ${ }^{41}$

Annexation is controversial and often leads to litigation. Annexation battles typically involve one of two contexts: when neighboring municipalities are competing for the same land area or when a municipality seeks to annex land from

\footnotetext{
${ }^{30}$ See DAvid Rusk, Cities Without Suburbs: A Census 2000 Update 108 (Woodrow Wilson Plaza ed., 3 d ed. 2003).

${ }^{31} I d$.

${ }^{32}$ Id. at $108-09$.

${ }^{33} I d$.

${ }^{34}$ See Edwards, supra note 14, at 124.

${ }^{35}$ See, e.g., Connolly, supra note 16 , at 82.

${ }^{36}$ IND. CODE ANN. § 36-4-3-3 et seq. (2011).

${ }^{37}$ KAN. STAT. ANN. § 12-520(a) et seq. (2011).

${ }^{38}$ See KRS § 81.100 et seq. (2012).

${ }^{39}$ See Neb. Rev. Stat. § 14-117 et seq. (2012).

${ }^{40}$ Tenn. Code AnN. § 6-58-111(a) et seq. (2011).

${ }^{41}$ See Tex. Local Gov’t COdE $§ 43.033$ et seq. (West 2012).
} 
its unincorporated environs. ${ }^{42}$ Those opposing annexations almost always include the landowners, businesses, and residents of the unincorporated area proposed for annexation, and sometimes residents of the county in whose borders the area falls. These groups are the most directly affected by proposed annexations. Annexations will likely result in a change to their tax liabilities or result in fee increases. Additionally, newly annexed residents may oppose the city's political regime. ${ }^{43}$ Opposition may also reflect the race and class politics of the metropolitan region. Suburban dwellers have traditionally been white and middle class, with their flight to the suburbs driven by a mix of factors that, together, have spurred suburban expansion and defined the modern suburban identity. ${ }^{44}$

In Cities without Suburbs: The 2000 Census Update, David Rusk makes the observation that around the middle of the twentieth century, "Washington, Wall Street, Detroit, Hollywood, and Madison Avenue" introduced the American middle class to a revision of the American dream that fundamentally reorganized land use and metropolitan organization and governance. ${ }^{45}$ The physical landscape of the metropolitan region and the distribution of neighborhoods, shopping areas, business districts, prosperity, and poverty are all the cumulative result of specific federal, state, and local policy decisions that developed from historical events, social processes, and economic forces. These forces have redefined the look, experience, and meaning of metropolitan space. They have resulted in the selective concentration of social activity and employment opportunities in a manner that has led to social polarization, spatial imbalances, and fragmented, uncoordinated government. ${ }^{46}$

In light of this history, urban sprawl cannot be attributed to just the cumulative impact of population growth, technology, or the lure of the suburbs. It is not just a rational rejection of city life, city politics, or urbanity. Urban sprawl

\footnotetext{
${ }^{42}$ See BRIFFAULT \& REYNOLDS, supra note 29, at 211.

${ }^{43}$ See Edwards, supra note 14, at 127-29.

${ }^{44}$ See infra note 48 and accompanying text.

${ }^{45}$ See RUSK, supra note 30 , at 7.

${ }^{46}$ See, e.g., Batchis, supra note 26 , at 379-83 (discussing the role of exclusionary zoning in the development of urban sprawl); Audrey G. McFarlane, Rebuilding the Public-Private City: Regulatory Taking's Anti-Subordination Insights for Eminent Domain and Redevelopment, 42 IND. L. REv. 97, 118-34 (2009) (discussing race and class subordination in redevelopment); John A. Powell \& Marguerite L. Spencer, Giving Them the Old "One-Two": Gentrification and the K.O. of Impoverished Urban Dwellers of Color, 46 How. L.J. 433, 436-48 (2003) (discussing the race, class, and spatial forces driving gentrification).
} 
reflects developments in the socio-cultural construction of the modern American middle class, the race and class struggles of the twentieth century, the massive federal subsidization of suburban growth policies, and exclusionary zoning. ${ }^{47}$ The confluence of these forces substantially redefined the meaning and experience of American life in a manner that transformed metropolitan regions by promoting, provoking, and facilitating an initial wave of white flight and a subsequent wave of multi-racial middle class flight that has decimated the tax base and urban core of metropolitan region central cities. ${ }^{48}$ This flight is quantifiable: in 1950, almost seventy percent of the population of 168 metropolitan regions lived in 193 central cities; by 2000, over sixty percent of the population of 331 metropolitan regions lived in suburbs. ${ }^{49}$ Over the same period, population density in 157 of those urbanized areas was effectively cut in half. ${ }^{50}$

The only central cities that added population during the past five decades without expanding their boundaries were Miami; San Francisco; Elizabeth and Patterson, New Jersey; and New York City. ${ }^{51}$ The states whose annexation regimes facilitate frequent municipal annexations of substantial landmasses are mostly

${ }^{47}$ See Rusk, supra note 30, at 24-25 (discussing Douglas S. Massey \& Nancy A. Denton, AMERICAN APARTHEID: Segregation AND THE MAKING OF THE UnDERClass (1993)) and JACKSON, supra note 17, at 195-203 (The Home Owners' Loan Corporation, which provided low-interest, longterm mortgage loans to financially struggling families created a neighborhood rating system that "redlined" predominately black neighborhoods, denying loans to families in those areas. The residential security maps that redlined black neighborhoods for disinvestment were regularly used by private banks for their lending practices and were embraced by the Federal Housing Administration and the Veterans Administration when they were founded in 1937 and 1944, respectively.).

${ }^{48}$ For a discussion of the causes and consequences of white suburban flight, see, e.g., Kyle Crowder, The Racial Context of White Mobility: An Individual-Level Assessment of the White Flight Hypothesis, 29 SOC. SCI. RES. 223 (2000) (presenting research that indicates that the likelihood of Whites leaving a neighborhood increases significantly with the size of the minority population in the neighborhood and that Whites are especially likely to leave neighborhoods containing combinations of multiple minority groups); George C. Galster, White Flight from Racially Integrated Neighborhoods in the 1970s: The Cleveland Experience, 27 URB. STUD. 385, 391 (1990) (presenting econometric research indicating that segregationist sentiment was a primary driver in white emigration from racially integrated neighborhoods); William Julius WilsON, WHEN WORK DisAPPEARS 25-50 (1996) (discussing the various factors characterizing the development of an isolated and economically disadvantaged ghetto underclass); see also generally BARRY SCHWARTZ, THE CHANGING FACE OF THE SUBURBS (1976).

${ }^{49}$ RUSK, supra note 30 , at 5 .

${ }^{50} I d$. at 8 .

${ }^{51}$ RUSK, supra note 15 , at 6. 
found in the nation's Sun Belt region. ${ }^{52}$ These states are where annexation activity has been the most frequent. ${ }^{53}$ Twenty-seven states have experienced significant annexation in the past twenty years due to aggressive expansions by their central cities. ${ }^{54}$ These twenty-seven states include almost all of the Sun Belt states, where population growth has been the steadiest and where most of the nation's growing mid-sized metropolitan regions are located. ${ }^{55}$ Their growth has undoubtedly allowed them to develop the infrastructure, population base, and economic preconditions necessary to enhance their economic competitiveness. ${ }^{56}$

The process of annexing territory is part of complicated reality of the meaning and function of municipal boundaries. Municipal boundaries are deliberate signifiers of cultural, social, and political identity in a community. They demarcate who is within and outside of a community and consequently who is entitled to participate in the redistribution of the community's wealth through public services and infrastructure. They reflect the nation's and the local community's legacy of race and class struggles and are as much of a reflection of those identity constructs

\footnotetext{
${ }^{52}$ See RUSK, supra note 15, at App. B (showing hyper-elastic and high-elastic cities almost exclusively located in sun-belt states, including Arizona, Nevada, Texas, North Carolina, Tennessee, Florida, New Mexico, Arkansas, South Carolina, and Alabama).

${ }^{53}$ See Colin C. Rice, Factors Contributing to Frequency of Municipal Annexation among Medium-sized Southern U.S. Cities 49-50 (2008) (unpublished M.P.A. thesis, Texas State University-San Marcos), http://ecommons.txstate.edu/arp/281.

${ }^{54}$ Rusk classifies these twenty-seven states as "big box" states. For the relevant regimes under the "big box" classification, see Ala. CODE § 11-42-1 (2011); Alaska STAt. § 29.06.040 (2011); ARIZ. ReV. StAT. ANN. § 9-471 (2011); ARK. COdE ANN. § 14-40-201 (2011); CAL. Gov’t CODE § 56017 (West 2011); Colo. Rev. Stat. § 31-12-107 (2011); Del. Code AnN. tit. 22, § 101 (2011); Fla. Stat. $\S 171.011$ (2011); Ga. CODE ANN. § 36-36-1 (2011); IDAHo CODE ANN. § 50-222 (2011); Ky. ReV. Stat. AnN. § 81a.005 (West 2011); LA. Rev. StAT. AnN. § 33:151 (2011); MD. Code AnN., art. 23a, $\S 19$ (West 2011); Miss. Code ANN. § 21-1-27 (2011); MonT. CODE ANN. § 7-2-4201 (2011); NeV. Rev. Stat. § 268.570 (2011); N.M. Stat. AnN. § 3-7-1 (2011); N.C. Gen. Stat. § 160a-45 (2011); OKLA. STAT. tit. 11, § 21-102 (2011); OR. REv. STAT. § 222.111 (2011); S.C. CODE ANN. § 5-3-110, repealed by An Act to Reform the Involuntary Annexation Laws of North Carolina 2011 N.C. SESS. LAWs 396; TENN. CODE ANN. § 6-51-102 (2011); TeX. Loc. Gov'T CODE § 43.001 (West 2011); UTAH Code AnN. § 10-2-401.5 (West 2011); W.VA. Code § 8-6-1 (2011); Wyo. Stat. ANN. § 15-1-401 (2011).

${ }^{55}$ A survey of the top 366 metropolitan regions in the United States with populations of between one half million and two million reveals that the majority of the areas are located in the South, Western Plains, and West Coast states. They developed primarily after the advent of the automobile and, in many cases, after the development of the interstate highway system. See infra note 79.

${ }^{56}$ Annexation served as the primary method of boundary growth for many metropolitan regions in the Sun Belt including: Houston, TX; Dallas, TX; San Antonio, TX; Phoenix, AZ. See Gerald E. Frug, Beyond Regional Government, 115 HARV. L. REV. 1763, 1766-73 (2002) (discussing annexation as a method of city building).
} 
as racial and socio-economic classifications themselves. ${ }^{57}$ Scholars have found that the more a region is fragmented into multiple governments or municipal identities, the more racially and economically segregated its housing market is and the slower its rate of regional economic growth. ${ }^{58}$ Intra-regional fragmentation both originates from and exacerbates existing social stratification and weak economic growth profiles.

Past motives for annexation have often intentionally served to reproduce preceding race and class inequalities. Annexations have, in many instances, been influenced by racial motives, carving metropolitan regions into racially and socioeconomically defined local government units. ${ }^{59}$ Municipal under-boundingannexation practices in which cities grow around or away from low-income minority communities in an effort to exclude them from municipal services and curtail their voting rights - has occurred in a number of states and is currently being challenged in the courts. ${ }^{60}$

\footnotetext{
${ }^{57}$ Numerous scholars have documented the lineage and effects of America's race- and class-conscious urban public policy, its relationship to the decline of central cities and the development and expansion of the modern American suburb, and the challenges it presents for the future organization of metropolitan regional politics and economic development. See, e.g., Anderson, supra note 16, at 935-37 (discussing the history of race and class influences on boundary construction); Cashin, supra note 2, at 2027-33 (discussing New Regionalism and the impact of local power in the reproduction of regional race, class and resource allocation disparities); Stahl, supra note 26 (discussing the class consciousness associated with suburban development and its relationship to zoning and notions of local autonomy in local government law).

58 See Rusk, supra note 15, at 2 (citing David Y. Miller, The Regional Governing OF Metropolitan AMERica 126-28 (2002)).

${ }^{59}$ See, e.g., Gillette, supra note 16 (discussing different theories and approaches to understanding the methodology of annexation and specifically promoting concurrent majorities as a method for conducting annexations); Anderson, supra note 16, at 937-41 (discussing municipal under-bounding as a motivation for annexation and as a reflection of the race and class dimensions of municipal boundary construction); Baumle et al., supra note 16 (discussing the role of annexation in diluting the weight of the votes of individuals who were in the city boundaries prior to annexation).

${ }^{60}$ See, e.g., Anderson, supra note 16, at 940. In Kennedy v. City of Zanesville, the United States District Court for the Southern District of Ohio found, on a motion for summary judgment, that a jury could conclude that the city's reasons for not providing public water to a group of African-American residents was based on pre-textual racial discrimination. 505 F. Supp. 2d 456, 498 (S.D. Ohio 2007). In Committee Concerning Community Improvement v. City of Modesto, the United States District Court for the Eastern District of California dismissed discrimination claims asserted by residents of a Latino community and two civic groups based on a lack of public service provisions from the city of Modesto California on a motion for summary judgment. The Ninth Circuit reversed the district court in regard to plaintiffs' claims under a Master Tax Sharing Agreement and the Fair Housing Act. The Ninth Circuit also reversed the district court's dismissal of plaintiffs' state law claims as well as the district court's award of costs to the defendants. 583 F.3d 690 (9th Cir. 2009). The case is currently on remand in the
} 
Various scholars' calls for increased annexation to address municipal underbounding reflect the negative consequences of fragmentation for historically marginalized communities and the risks posed by annexation for community residents. ${ }^{61}$ Because of statutory requirements and local government practice, proposed annexations must always consider the fiscal impact of a boundary expansion. ${ }^{62}$ This analysis requires weighing the proposed annexation's service costs and revenue benefits. This utilitarian approach can mask race and class animus, ultimately disadvantaging lower income or minority unincorporated areas that lack an attractive property or retail tax base. ${ }^{63}$

Race and class bias in annexation reflect deeper conflicts located at the intersection of property rights and redistribution. Just as private property boundaries grant the individual the right to exclude others from the bundle of rights and social, political, and economic benefits tied to private property, city boundaries also serve an exclusionary function by determining who gets to participate in the redistribution of a community's resources. When applied to the role of municipal boundaries in shaping notions of community, the exclusionary features of private property ownership are elevated as the essential features worthy of attention and protection. This leads to a crisis of political discourse where notions of private property rights are expressed through the formation and reformation of municipal boundaries.

Frank Sengstock began his 1960 book, Annexation: A Solution to the Metropolitan Problem, with the contention that "[ $[\mathrm{t}] \mathrm{he}$ outstanding demographic characteristic of the twentieth century United States is the intensive development of metropolitan areas unrestrained by local political boundaries." ${ }^{.64}$ As the twenty-first century unfolds, the implications of Sengstock's observations are clear in the land

Eastern District of California and undergoing pre-trial preparation. See Comm. Concerning Cmty. Improvement v. City of Modesto, 2011 U.S. Dist. LEXIS 13774 (E.D. Cal. 2011).

${ }^{61}$ See Anderson, supra note 16, at 938-42.

${ }^{62}$ See Edwards, supra note 14, at 127-29.

${ }^{63}$ See, e.g., Anderson, supra note 16, at 944-59; Connolly, supra note 16, at 82-85 (discussing the selective annexation of wealthy areas and the exclusion of poorer areas with high minority populations in recent North Carolina annexation cases); Edwards, supra note 14, at 123 (citing D. Andrew Austin, Politics vs. Economics: Evidence from Municipal Annexation, 45 J. URB. Econ. 501 (1999) (discussing empirical analysis that suggests that the fiscal motive of capturing additional tax base did not necessarily drive annexation decisions and that, while decision-makers do not necessarily pick and choose amongst census tracts to minimize nonwhites included in an annexation, results do show that decision-makers used annexation to increase the proportion of white voters and dilute minority voting power)).

${ }^{64}$ SENGSTOCK, supra note 29 , at 1. 
use and demographic characteristics of American metropolitan regions. Annexation remains the dominant driver of municipal expansion. ${ }^{65}$ A half century of suburban growth politics, however, has undermined the public's understanding of annexation. ${ }^{66}$ Annexation is now widely perceived as a threat to individual liberty and autonomous self-government, pitting metropolitan region residents against metropolitan region central city governments. ${ }^{67}$

A more useful frame for conceptualizing annexation policy recognizes its potential to both strengthen regional economic development efforts and curb the continued growth in race and class stratification. This potential is even greater for mid-size metropolitan regions. These regions face unique economic development challenges that arise out of a fundamentally distinct set of historical and urban development realities that separate them from large metropolitan regions. ${ }^{68}$ While large metropolitan regions have many tools to lure and retain mobile capital, midsize metropolitan regions typically have less leverage and therefore must reconsider central city expansion and the organization of metropolitan governance through annexation.

\section{PART II: The Mid-Size Metropolis ANd The AnNeXation IMPERATIVE}

In order to fully comprehend annexation's potential for bolstering the economic competitiveness of mid-size regions, it is necessary to investigate the relationship between boundary elasticity and economic competitiveness. First, it is necessary to define exactly what constitutes a mid-size metropolitan region and how it differs from its larger counterparts. This examination must consider the relatively diminished competitive capacity of mid-size regions in the context of the

\footnotetext{
${ }^{65}$ Boundary expansion was the largest driver of municipal expansion in the second half of the twentieth century, with almost four-fifths of 521 central cities expanding their boundaries by ten percent or more between 1950 and 2000. For the decade between 1970 and 1979, municipalities undertook over 61,000 annexations and about the same number for the fifteen-year period from 1990 to 2005. Edwards, supra note 14 , at 119 . During the 1990 s, 348 of 400 central cities that could annex property did. RUSK, supra note 30 , at 108 .

${ }^{66}$ See Briffault, supra note 8, at 357-66.

${ }^{67}$ Whether or not pro-municipality annexation policies are inherently oppositional to individual property rights is a topic that deserves a more robust treatment than this article is concerned with. See, e.g., Gillette, supra note 16; RUSK, supra note 30, at 108-10 (arguing that annexation laws have an impact on a city's flexibility); Laurie Reynolds, Rethinking Municipal Annexation Powers, 24 URB. LAW. 247, 250, 258-71 (1992) (arguing that involuntary annexation power is necessary for all municipal government).

${ }^{68}$ See infra note 90 and accompanying text.
} 
ever-intensifying pressures on metropolitan capital attraction efforts. Lastly, this examination must explore the specific challenges mid-size regions face in resolving global inter-urban competition with their historically low level or lack of participation in that competition.

\section{A. Metropolitanization and Defining the Mid-Size Metropolis}

All cities are not created equal, and mid-size metropolitan regions receive scant attention in urban policy analysis. Few scholars have explored the distinctiveness of mid-size metropolitan regions or the substantive policy considerations that emanate from that distinctiveness. ${ }^{69}$ Mid-size metropolitan regions face many of the same growth and global competitiveness challenges as their larger counterparts, yet generally with less intensity and fewer available resources. ${ }^{70}$ In most cases they lack the image, economic and population diversity, and the real and perceived quality of life advantages that large urban regions have in abundance. ${ }^{71}$

Large metropolitan regions are the dominant frame of reference for discussions of metropolitanization, urban complexity, and urban policy innovation. They are the conceptual center from which most urban-related knowledge is developed and critiqued. ${ }^{72}$ Large metropolitan central cities are internationally known for their distinct identities, histories, architecture, and culture. They are destinations that leverage their scale to attract and develop a range of resources that

\footnotetext{
${ }^{69}$ The scholarship on mid-size cities and metropolitan regions reveals varying definitions of "mid-size." There is a broad recognition in the scholarship of the mid-size city/region's largely ignored and undervalued distinctiveness relative to its larger counterparts and the general lack of attention this has received in scholarship. See generally Pierre Filion \& Trudi Bunting, Exploring Policy Implications of Metropolitan Size: Accounting for the Mid-Size Urban Area, in GoverNING METROPOLISES: PROFILES OF ISSUES AND EXPERIMENTS ON FOUR CONTINENTS 87 (Jean-Pierre Collin \& Mélanie Robertson eds., 2007); Trudi Bunting et al., Density, Size, Dispersion: Towards Understanding the Structural Dynamics of Mid-Size Cities, 16 CANADIAN J. URB. RES. 27, 46 (2007) ("Mid-size cities suffer from a scarcity of planning models suited to their particular circumstances, in part because there has been little recognition of their distinctive status.").

${ }^{70}$ For a definition of mid-size metropolitan regions and large metropolitan regions, see infra note 79 and accompanying text.

${ }^{71}$ Ethnic and racial diversity is primarily prevalent in large metropolitan areas. See U.S. CENSUS Bureau, Statistical Abstract of the United States: 2012, at 31 tbl. 23 (2012), available at http://www.census.gov/compendia/statab/2012/tables/12s0023.pdf.

72 See generally Neal R. Peirce, Citistates: How Urban America Can Prosper in a Competitive WORLD (1993). See also Filion \& Bunting, supra note 69, at 106 (discussing a ten-year survey from the Journal of the American Planning Association that revealed that a majority of the cities cited belonged to metropolitan regions with populations greater than one million).
} 
contribute to their quality of life and livability. In addition to physical scale, they have the advantage of symbolic scale - the scale of history and cultural narrative. They are repositories of urban history, the impact and import of which stretches far beyond their boundaries.

Large metropolitan regions also have a concentration of business and industry and the magnetic draw of a diverse, dynamic, and youthful population. Their geographic position and climate profile, historic patterns in the development of interstate commerce and transportation systems and embedded cultural economies, and their symbolic significance within larger narratives of community and identity make them well positioned to satisfy the tastes and preferences of twenty-first century life. $^{73}$

New York, Chicago, Philadelphia, Los Angeles, and others have welldeveloped cultural identities that serve as powerful leverage for the economic development aims of their metropolitan regions. ${ }^{74}$ Their relative concentration of population, culture, firms, and infrastructure validate their position as global cities and make them magnets for global firms seeking durable preconditions for economic growth. ${ }^{75}$ These assets have developed over time and amount to legacy factors that endow large metropolitan regions with a critical mass of competitive credentials. These credentials serve as powerful leverage for their competitive positioning. Ultimately, large metropolitan regions have many options for reconciling the ever-unfolding dynamics of inter-urban competition for mobile capital with fragmentation and the challenges of metropolitan economic development coordination.

Given these observations, the impact of intra-regional fragmentation takes on a different character in mid-size regions than in large regions. ${ }^{76}$ As municipalities

\footnotetext{
${ }^{73}$ See, e.g., Mario Polèse, Why Big Cities Matter More than Ever: Seven Reasons, 20 City J., No. 4, 2010, available at $\mathrm{http}: / / \mathrm{www} . c i t y-j o u r n a l . o r g / 2010 / 20 \_4$ big-cities.html.

${ }^{74}$ The development of these cultural identities are deliberate and are part of the way in which cities and metropolitan regions market and promote themselves, primarily for tourism, which presents considerable revenue-generating opportunities for municipalities and their businesses. These efforts are known as "place branding." Place branding "refers to the broad set of efforts by country, regional and city governments, and by industry groups, aimed at marketing the places and sectors they represent" for the purpose of "attract[ing] or retain[ing] factors of development and generally position[ing] the place for [more] advantage[ous] domestic[] and international[] [positioning] in economic, political and social terms." Nicolas Papadopoulos, Place Branding: Evolution, Meaning and Implications, 1 PLACE BRANDING 36, 36-37 (2004).

${ }^{75}$ See generally Erla Zwingle, Megacities, NAT'L GeOGRAPHIC, Nov. 2002, at 70.

${ }^{76}$ See, e.g., Briffault, supra note 8 . Briffault discusses how the mobility of people in a multiplicity of localities in a metropolitan region can erode the capacity of most cities to undertake new programs that
} 
of all sizes wrestle with crumbling infrastructure, unfunded pension liabilities, and tax bases diminished by decades of suburban flight, the physical, economic, and symbolic advantages of large urban regions can tip the scales of relative success and survival. These challenges are magnified for mid-size regions relative to their capacity for competing for mobile capital.

Mid-size metropolitan regions often do not possess the same status, cultural profile, economic base, and critical mass of legacy factors as large metropolitan regions. They often lack the leverage to compete in an increasingly high-stakes inter-urban or inter-municipal competition for mobile capital. ${ }^{77}$ The unique challenges that stem from their economic structure, urban form, built environment, quality of life, and governance are of sufficient magnitude as to require separate consideration in urban studies and in local government law.

There are various methods of defining what qualifies as a mid-size metropolitan region, and it is possible to overstate the importance of size, given that metropolitan regions confront many of the challenges that, regardless of scale, require the same types of skills and resources to address. ${ }^{78}$ This author's definition of a mid-size metropolitan region focuses on those regions in the United States with populations between one half million and two million. Metropolitan regions within this band are distinctly different from regions with populations less than one half million or those with more than two million. ${ }^{79}$

would impose costs on already strained local budgets. Additionally, the expansion of public services will likely be perceived to benefit the poor, racial minorities or municipal workers at the expense of higher tax-paying individuals and businesses. In mid-size cities, the combination of higher race and class polarization and relatively undeveloped economic bases only exacerbates the dynamics Briffault describes.

${ }^{77}$ See id.

${ }^{78}$ Various studies offer customized definitions of what constitutes a mid-size metropolitan region. Methods differ depending upon the objective of a particular study. See, e.g., Filion \& Bunting, supra note 69 , at $88-89$ (defining mid-size as between 100,000 and 500,000).

${ }^{79}$ Metropolitan regions with populations less than one half million tend to consist of small cities and towns, with smaller satellite towns comprising a total metropolitan region. These metropolitan regions include those of Spokane, Washington; Flint, Michigan; Shreveport, Louisiana; Erie, Pennsylvania; Charlottesville, Virginia; and Santa Fe, New Mexico. See U.S. Office OF Mgmt. \& Budget, 366 Metropolitan Statistical AReas for the United States of America (2010), available at $\mathrm{http}: / /$ www.census.gov/population/metro. Metropolitan regions with populations greater than two million tend to consist of large, symbolic, well-branded metropolitan regions that, because of their scale and legacy factors, have a wide diversity of people and firms. These regions include those of New York, New York; Houston, Texas; Washington, DC; Denver, Colorado; and Cincinnati, Ohio. For reference, the April 1, 2010, update of the United States Office of Management and Budget's ranking of the top 366 MSAs lists twenty-nine metropolitan regions with populations of more than two million, 
The United States Office of Management and Budget (OMB) has developed and manages an index of metropolitan statistical areas (MSAs) that ranks metropolitan regions according to population size and gives definition to the municipalities and jurisdictions that make up each metropolitan statistical area. ${ }^{80}$ This ranking provides the best baseline for the concerns of this article, specifically in defining what constitutes a mid-size metropolitan region.

While population numbers are central to this article's consideration of midsize metropolitan regions, population alone is insufficient to understand the differences between mid-size and large metropolitan regions. Density is one of the key metrics for understanding the spatial relationships of cities and metropolitan regions. ${ }^{81}$ For the majority of mid-size central cities, densities have never been high, and their overall development is characterized by low-density spatial forms that are relatively constant across traditional downtown areas and suburban areas alike. The land use and transportation patterns of mid-size metropolitan regions generally follow low-density, decentralized, automobile-oriented land use patterns. $^{82}$

representing the top eight percent in number and the top fifty-two percent in population of the 366 MSAs. MSAs ranked numbers 30 to 102 fit this definition of mid-size, comprising twenty-six percent of the population of the 366 MSAs. The Las Vegas, Nevada, MSA ranks 30th with a population of $1,951,269$. The Durham-Chapel Hill, North Carolina, MSA ranks 102nd with a population of 504,357.

This author appreciates that a mid-size metropolitan region classification based solely on a region's population may overstate the role that population size plays in determining the economic competitiveness of a given metropolitan region. For instance, both New Orleans, Louisiana, and Las Vegas, Nevada, fall within this author's definition of mid-size metropolitan regions. These areas arguably possess many of the same legacy credentials that larger population centers do, specifically in terms of brand capital and external recognition. While the classification used herein presents a higher floor and ceiling for the definition of "mid-size metropolitan region" than has been used in other studies, the emergence of global cities and the regional considerations at the core of the arguments presented herein require a definition of "mid-size metropolitan region" that reflects global realities, specifically with regards to the rise of global cities and global inter-urban competition.

${ }^{80}$ The United States Office of Management and Budget (OMB) defines a Metropolitan Statistical Area (MSA) as a Core Based Statistical Area having at least one urbanized area of 50,000 or more population, plus adjacent territory that has a high degree of social and economic integration with the core as measured by commuting ties. The OMB has defined 366 MSAs for the United States as of March 29, 2010. See U.S. OfFICE OF MGMT. \& BudGeT, supra note 79.

${ }^{81}$ See FULTON ET AL., supra note 1, at 3-4.

${ }^{82}$ Because of the dearth of substantive research focused on mid-size metropolitan areas, this author relies on personal observations. For a discussion of the relationship between density, land use, and the automobile, see generally Edward H. Ziegler, Urban Sprawl, Growth Management and Sustainable Development in the United States: Thoughts on the Sentimental Quest for a New Middle Landscape, 11 VA. J. SOC. POL'Y \& L. 26 (2003); Filion \& Bunting, supra note 69. 
The mid-size region is defined by the relative pervasiveness of the lowdensity form. ${ }^{83}$ Mid-size regions are likely at a disadvantage to their larger, denser counterparts because they lack the dense urban form dynamics that are endemic to places high in economic development activity. These more dense urban forms and land use patterns can achieve greater economies of scale by reducing the per capita costs of service delivery and infrastructure development. ${ }^{84}$

Most mid-size regions developed in the twentieth century. Early in the twentieth century, several developments emerged that would shape land use, zoning, and the politics of boundary formation and reformation for the entirety of the twentieth century. Two of the most significant developments were the emergence of the automobile and intense race and class strife. ${ }^{85}$ These dynamics produced specific land use patterns that shaped mid-size regions differently than older, larger regions. The resulting land use dynamics are characterized by multiple dispersed activity nodes across a relatively low-density built environment. This has, in some cases, produced irregular land uses and correspondingly irregular land values. These dynamics complicate the physical proximity necessary for the type of market exchanges that drive economic development in urban centers. ${ }^{86}$

One key distinction of the mid-size region is the relative lack of activity in the central city core. ${ }^{87}$ As a result of the relative lack of economic, social, and cultural activity occurring in their downtowns, mid-size regions rarely have well-developed inner-city land use and transportation dynamics that allow for high-density housing and commercial development arrangements on a meaningful scale. ${ }^{88}$ Downtown stabilization and revitalization largely depends on the presence of an effective and

${ }^{83}$ See, e.g., Bunting et al., supra note 69, at 29-30.

${ }^{84}$ See, e.g., Jan K. Brueckner, Urban Sprawl: Diagnosis and Remedies, 23 InT'L REGIONAL SCI. REV. $160,166-67$ (2000) (discussing market failure in the context of urban sprawl through the failure to fully account for the infrastructure costs of new development).

${ }^{85}$ See, e.g., Gomillion v. Lightfoot, 364 U.S. 339 (1960) (invalidating an Alabama law redefining the municipal limits of Tuskegee upon a finding that the boundary redefinition was motivated by a desire to disenfranchise black citizens); Cashin, supra note 2, at 1993 ("By delegating nearly complete authority to control land use to the lowest incorporated governmental units, state governments have created a social, fiscal, and political environment in which suburban jurisdictions are rationally motivated to use highly exclusionary zoning and developmental policies, and homogeneous localities can give effect to their worst biases.") (internal quotations and citations omitted).

${ }^{86}$ See Filion \& Bunting, supra note 69 , at 90-91.

${ }^{87}$ See Bunting et al., supra note 69 , at $41-42$.

${ }^{88}$ See id. at $41-46$. 
heavily used transit system, a major employment cluster, a dense inner city, and tourist appeal-traits usually lacking in mid-size regions. ${ }^{89}$

Land use and transportation networks characterized by core area depletion and expansive suburban sprawl impact the economic development profile of midsize regions in a manner markedly different than larger, older, denser, and more diverse population centers. ${ }^{90}$ Consequently, mid-size metropolitan regions complicate prevailing notions of what constitutes the urban and the suburban. Prevailing stereotypes of urban and suburban development most commonly associated with large regions are insufficient when applied to mid-size metropolitan development patterns and land uses. Mid-size regions are typically less dense throughout their regions, while large urban regions typically have dense central cities and less dense suburban communities. Therefore, mid-size regions do not easily fit into the traditional city/suburb framework that is the focus of most metropolitan governance studies. ${ }^{91}$

For many mid-size regions, particularly those in the Sun Belt region, the majority of the infrastructure development and land use decisions were made after the advent of the automobile and interstate system. ${ }^{92}$ When President Dwight Eisenhower signed the Federal Highway Act of $1956,{ }^{93}$ which authorized the funding of the interstate highway system and consequently accelerated the development of suburban communities on the periphery of the nation's major cities, mid-size cities like Memphis, Tennessee, and Raleigh, North Carolina, were considerably smaller than they are today. ${ }^{94}$ Their development patterns and spatial

${ }^{89}$ See Filion \& Bunting, supra note 69.

${ }^{90}$ See Bunting et al., supra note 69 , at 46-47.

91 U.S. cities overall do not rank high in population density when considered among the ranks of emerging global cities. Los Angeles, California (the city proper, as opposed to the metropolitan region) is the country's most dense city with a 2007 population of $11,789,000$ over 2684 square miles, or 4392 people per square mile. This is unremarkable when compared to the world's most dense city, Mumbai, India, which has 47,833 people per square mile. New York, on the other hand, is less dense than Los Angeles with 3299 people per square mile. In comparison to Los Angeles, U.S. cities located in mid-size metropolitan regions - regions between two million and one half million in population-have density numbers that range from the unusually high 3173 people per square mile in New Orleans, Louisiana to the more common 769 people per square mile in Knoxville, Tennessee. The Largest Cities in the World by Population Density, CiTY MAYORS (Jan. 6, 2007), www.citymayors.com/statistics/largest-citiesdensity-125.html (statistics used in this work reflect a conversion from kilometers to miles).

${ }^{92}$ See BRIFFAULT \& REYNOLDS, supra note 29.

${ }^{93}$ Pub. L. No. 84-627, 70 Stat. 374.

94 See World Population Prospects: The 2010 Revision, U.N. DePARTMENT ECON. AND Soc. AfF., http://esa.un.org/unpd/wpp/Documentation/publications.htm (last visited Oct. 18, 2012). 
arrangements therefore mirrored a more suburban form, even in the core of their central cities.

Because mid-size regions are generally less dense than larger regions, their residents' motivations for moving within the region may differ from those of larger regions. For instance, in large metropolitan regions, the urban core usually contains dense development patterns that include multi-family complexes, row house developments, and other small-lot, single-family dwellings. These land-use arrangements do not allow for an abundance of private land and, consequently, outdoor recreational activities are usually relegated to public parks and other public spaces.

Given the pervasiveness of low-density development patterns in mid-size central cities, it is possible that movement within mid-size regions is spurred less by a desire for more space and more by a desire to associate or disassociate with groups depending upon one's social position. This desire is often reflected in the local politics of race, class, and public schools - a discourse especially relevant for understanding social divisions in mid-size regions. ${ }^{95}$ A determined cohort of residents moving to peripheral areas adjacent to the municipal and school district boundaries could eventually develop the critical mass necessary to support their own autonomous entities. ${ }^{96}$ When these settlements form, they often are amenable to higher property taxes to support their own school district and government structures, indicating that their objection to being in the central city boundaries may not be higher taxes, but rather the redistribution of their tax dollars to support infrastructure and services for disfavored groups. ${ }^{97}$

Mid-size regions and large regions share the effects of metropolitanization on their land use patterns. Metropolitanization is the process by which a central city evolves to become a component of a larger regional entity that includes outside environs - suburbs, exurbs, and surrounding rural areas - that are tied to the central city by employment, commerce, mass communications, economic interdependence, and cultural and identity ties. ${ }^{98}$ Metropolitanization in the United States is largely the result of early twentieth-century social and political alignments and related

\footnotetext{
${ }^{95}$ See, e.g., Charles R. Lawrence III, Forbidden Conversations: On Race, Privacy, and Community (A Continuing Conversation with John Ely on Racism and Democracy), 114 YALE L.J. 1353 (2005).

${ }^{96}$ See Cashin, supra note 2, at 1992-96.

${ }^{97}$ See id.

${ }^{98}$ See, e.g., Richard Briffault, The Local Government Boundary Problem in Metropolitan Areas, 48 STAN. L. REV. 1115, 1116-17 (1996).
} 
economic developments that resulted in the geographic expansion of social, economic, and cultural life from the central city core.

As a consequence of metropolitanization, people no longer live their daily lives wholly in individual cities and towns or in singular municipal units. Eightfour percent of Americans now live in a metropolitan region. ${ }^{99}$ Fifty-eight percent of the workers in metropolitan regions commute to jobs in a city or town different from the one in which they live but still within their metropolitan region. ${ }^{100}$ Seventy-nine percent of metropolitan region residents who move choose another location in the same metropolitan region. Residents of metropolitan regions may live within separate geographic and political sub-units of the broader metropolitan region yet shop in different parts of metropolitan regions, receive "local" media from metro-wide newspapers and television stations, and root for sports teams and visit cultural institutions that represent and service an entire metropolitan region.

Metropolitan regions represent the critical geographic lens through which it is possible to define and critique contemporary American society. ${ }^{101}$ They provide a window into the impact of geoeconomic realignments that have focused economic matters away from nation-states and towards metropolitan regions or, as they have been termed by some scholars, "citistates." ${ }^{102}$ For at least the past two decades, urban research scholars have understood that American central cities are not only competing with their suburbs but also with metropolitan regional economies all over the globe. ${ }^{103}$

Metropolitan regions are the dominant political and economic units through which the capital attraction motives of local governments are expressed. They are commonly identified by their central city anchors. For instance, the Los AngelesLong Beach-Santa Ana, California, MSA is commonly known as Los Angeles. ${ }^{104}$

99 Brookings inst. Metro. Policy Program, the State of Metropolitan America: On the Front LiNES OF DEMOGRAPHIC TRANSFORMATION 16 (2010).

${ }^{100} I d$.

${ }^{101} I d$.

${ }^{102}$ See generally PEIRCE, supra note 72.

${ }^{103}$ See, e.g., Kingsley E. Haynes \& Roger R. Stough, The Federal Urban Policy Agenda: Recent Past and New Realities, 551 AnNALS AM. ACAD. POL. \& SoC. SCI. 73 (1997); Michael Stegman \& Margery Austin Turner, The Future of Urban America in a Global Economy, 62 J. Am. PLANNING Ass'N, Spring 1996, at 157.

104 See U.S. OfFice of Mgmt. \& Budget, supra note 79; U.S. Census Bureau, Metropolitan and Micropolitan Statistical Areas and Components (2010), http://www.census.gov/population/metro (exhibiting that metropolitan areas are generally named based upon the largest municipality included in 
Employment growth is essential to metropolitan economic well-being; therefore, capital attraction is increasingly the primary focus of metropolitan economic development efforts. ${ }^{105}$ The central city of a metropolitan region-the largest or most commonly identified city in the region - must be healthy, vibrant, and ripe for economic possibility if the region is to prosper. Many of those central citiesparticularly those anchoring mid-size regions - have spent the past many decades contending with ever-increasing patterns of out-migration and suburbanization that have sucked people, firms, livelihoods, and tax revenue out of central cities and displaced them throughout the region.

The mid-size region traditionally has offered few options for meaningful outmigration to developed areas not yet under the control of the central city government. Given the relatively thin economic base and historically low growth rates of many of these communities, suburban growth is often slow and sparse, with many areas retaining rural characteristics as they slowly develop a suburban identity. ${ }^{106}$ The lack of worthwhile escape options colors the approach to managing social hierarchy. These dynamics impact the social construction of place and a community's determinations of what constitutes favored and disfavored identity within the metropolitan region.

Notions of favored and disfavored identity - as typically expressed in race and class struggles - are inextricably connected to commonly held beliefs about the bundle of rights associated with private property as well as the social construction of municipal boundaries. ${ }^{107}$ They are deeply intertwined with current trends in urban redevelopment and its over-focus on the gentrification of urban space to create amenities and privatized spaces for the affluent. ${ }^{108}$ These trends often result

the metropolitan area). For an explanation of the standards used to determine how metropolitan and micropolitan statistical areas are defined, see 2010 Standards for Delineating Metropolitan and Micropolitan Statistical Areas, 75 Fed. Reg. 37,246 (June 28, 2010).

${ }^{105}$ See, e.g., Richard C. Schragger, Reassessing the State and Local Government Toolkit: Rethinking the Theory and Practice of Local Economic Development, 77 U. CHI. L. REV. 311, 338-39 (2010).

${ }^{106}$ See Filion \& Bunting, supra note 69 , at 87-114.

107 See, e.g., Cheryl I. Harris, Whiteness as Property, 106 HARV. L. REV. 1707, 1713-14 (1993) (discussing whiteness as treasured property in a society structured on racial caste and how, over time, the benefits and expectations associated with the privileges of whiteness have been affirmed, legitimated and protected by the law); Anderson, supra note 16, at 940 (discussing the racial segregation function of municipal boundaries); Rolf Pendall, Local Land Use Regulation and the Chain of Exclusion, 66 J. AM. PLANNING Ass'N 125, 126-27 (2000) (discussing exclusionary land use controls and how municipal governments have fostered racial discrimination and exclusion through zoning).

${ }^{108}$ See McFarlane, supra note 46, at 113-18 (discussing the prioritization of the consumption needs of the affluent and the promotion of land uses, amenities, and aesthetics in contemporary urban 
in the subordination of disfavored identity groups that are not only socially marginalized in these processes, but for whom insufficient options are made available through urban redevelopment's remaking of urban spaces. This, in turn, reduces their presence in urban spaces. ${ }^{109}$

The relative paucity of options in a low-density, yet territorially compact, environment for favored groups to meaningfully spatially separate from disfavored groups intensifies the nature of the social stratification existing therein. Consequently, in mid-size regions, resettlement on the periphery of the central city boundaries may reflect a more conscious and deliberate rejection of the central city's demographics than may be the case in larger regions. ${ }^{110}$

The role these sociological factors play in the making and remaking of municipal boundaries is exacerbated by the ascendance of a general culture of mass affluence. The sociopolitical implications of late trends in consumerism heighten the focus on real class status as measured by perceived consumer segment performance. ${ }^{111}$ This reinforces notions of favored and disfavored identity, consequently defining notions of who belongs in communities in part by municipal boundaries. The relatively constrained local economy and territorially compact nature of mid-size regions magnifies the dynamics of this race and class stratification, resulting in more acute social divisions than may exist in a large metropolitan region. ${ }^{112}$ Furthermore, many of these regions are within states that are home to sedentary family structures, meaning that an overwhelming majority of

redevelopment ventures that appeal to the sensibilities and tastes of the affluent at the expense of more inclusive and equitable methods of land use).

${ }^{109}$ See id.

${ }^{110}$ Large metropolitan central cities often see the very wealthy and the very poor living within the central city while the middle class - who both cannot afford the central city's wealthier areas and who are fleeing any proximity to the central city's poorer areas - are relegated to the urban fringe.

${ }^{111}$ For a more in-depth discussion on the relationship between global consumer identity formation, mass affluence, and urban real estate development trends, see generally McFarlane, supra note 46, at 124-28 (2009) (discussing clustering, geo-demographic profiling, and other methods of advanced marketing and consumer segmentation that produce new forms of social and economic exclusion masked as identityneutral responses to observable, quantifiable market behavior).

${ }^{112}$ While the author remains unaware of any available studies exploring this phenomenon, this author draws on personal observations of the intensified race and class divisions existing in mid-size urban settings as compared to large urban settings. In large urban settings, race and class groups have the space to develop sizeable, self-contained and racially homogenous neighborhoods that preclude the need to co-mingle with other groups. In the mid-size setting, however, this author's personal observations reveal that the relative lack of meaningful spatial separation necessitates the development of social norms that enforce a race- or class-based social order. 
the residents are from the state. ${ }^{113}$ The higher sedentary family structure rate likely reflects relatively low levels of in-migration, which may reflect a lack of competitive and quality employment prospects to lure new residents in. It also adds an inter-generational character to the social patterns that, over time, magnify the stigmas tied to place.

Many mid-size regions' central cities are facing declining populations and constricting tax bases amidst rapidly complexifying geoeconomic competitive forces. ${ }^{114}$ They risk ending up with relatively less dynamic regional economies, which makes attracting and retaining new investments more difficult and the consequences of failing to do so all the more dire. Because of these and other realities, mid-size regions are considerably more exposed to the underside of global inter-urban competition for mobile capital. The expansion of central city boundaries is one of the most efficient methods for achieving the regional municipal consolidation needed to spur overall regional growth and economic competitiveness in mid-size regions. ${ }^{115}$

\section{B. The Mid-Size Metropolis, Economic Development and Mobile Capital}

For many mid-size central cities, property value appreciation and population growth occur away from the central city or regional core, intensifying fragmentation patterns. ${ }^{116}$ These mid-size central cities are disproportionately home to their region's neediest residents - those left behind by cycles of out-migration. Consequently, they face the challenge of providing infrastructure and leading regional economic development efforts while burdened by a declining tax base and an increasingly fragmented system of metropolitan governance. While fragmentation may not be determinative of economic competitiveness in every

\footnotetext{
${ }^{113}$ Louisiana, for instance, is said to have the most sedentary family structure in the nation, with $79 \%$ of its current residents having been born in Louisiana. See Blaine Harden \& Shankar Vedantam, Many Displaced by Katrina Turn to Relatives for Shelter, WASH. Post, Sept. 8, 2005, at A01.

${ }^{114}$ See Bunting et al., supra note 69.

${ }^{115}$ While this article focuses on annexation as a tool for facilitating regional governance, there exist other examples — although few — of relatively successful regional governments. Minnesota's Twin Cities region is frequently lauded as a model of regional governance. Since 1994, the Metropolitan Council of the Twin Cities has exercised jurisdiction over all sewer, transit, and land use planning for the seven counties and 188 cities within the Minneapolis-St. Paul, Minnesota, metropolitan region. See, e.g., MYron ORFIELD, METROPOLITICS 13 (1997).

${ }^{116}$ See Bunting et al., supra note 69 , at 46 (explaining that, due to the supply of relatively cheap land and the pervasiveness of the automobile, most employment nodes in mid-size regions are found well outside of the core, dictating settlement and development trends).
} 
case, it can thwart the efficient development of a regional economic development program that reflects the global intra-urban competitive landscape. ${ }^{117}$ Ultimately, the combined force of these factors complicates regional economic development capacity at a time of increasing global inter-urban competition.

Various studies support the contention that fragmentation is bad for metropolitan economic development efforts. For instance, a higher number of counties in a metropolitan region can have a negative effect on infrastructure expenditures. ${ }^{118}$ Rusk's Annexation and the Fiscal Fate of Cities formulates a statistical link between fiscal health and inelastic cities - cities that are, or have in the past been, unable to expand their boundaries over time. ${ }^{119}$ The report's findings support the contention that a city's ability to annex land from its surrounding county is one of the primary determinants of its fiscal health and that cities with greater capacity to annex have much higher bond ratings. ${ }^{120}$

Boundary elasticity determines how well a city succeeds in maintaining its market share of sprawling growth - a dominant factor in determining municipal bond ratings. Rusk's findings showed that inelastic cities are highly dependent on state bailouts and outside financing for major regional investments. Such inelastic cities are concentrated in the Northeastern and Midwestern states. Cities located in states with annexation regimes that allow for high levels of boundary elasticity are fiscally healthier and arguably more competitively positioned for economic development success. ${ }^{121}$

Countering Rusk's position is a long line of urban studies local government law scholarship extolling the benefits of municipal fragmentation. ${ }^{122}$ They reflect

${ }^{117}$ See Carruthers \& Ulfarsson, supra note 1, at 316-20.

${ }^{118}$ See, e.g., Markus Berensson, Government Fragmentation is Holding Back America's Metropolitan Regions, CITY MAYORS (May 3, 2011, 11:25 AM), http://www.citymayors.com/government/usgovernment-fragmentation.html; see also Markus Berensson, Metropolitan Fragmentation and Economic Growth (Jan. 2011) (unpublished thesis) (on file with author).

${ }^{119}$ See RUSK, supra note 15, at 2, 6. But see Edwards, supra note 14, at 133 (citing studies that call into question the empirical evidence supporting Rusk's prescriptions for central city decline, including enhanced annexation powers); Mary M. Edwards \& Yu Xiao, Annexation, Local Government Spending, and the Complicating Role of Density, 45 URB. AFF. REv. 147, 162-64 (2009) (finding that the net fiscal outcome of annexation actually depends on the relative strength of changes in both land area and population density, holding socioeconomic and geographic variables constant).

${ }^{120}$ See RUSK, supra note 15 , at 6.

${ }^{121}$ See id. at 7.

${ }^{122}$ See generally Charles Tiebout, A Pure Theory of Local Expenditures, 64 J. POL. ECON. 416 (1956) (arguing that metropolitan residents are essentially "consumer voters," and that the greater the number 
the ideology of what local government law scholar Richard Briffault has termed "localism": the ability of unincorporated areas to determine whether or not they desire to be annexed purely according to localist considerations and without any consideration of or regard for the metropolitan region as a whole. ${ }^{123}$

Proponents of intra-regional competition and local government fragmentation underestimate ever-evolving geoeconomic realities. Their logic, if continued, will ultimately hamstring the ability of mid-size regions to remain competitive. The efficiency and sociological arguments in favor of greater annexation powers for central cities are compelling and paint an empirically grounded cautionary tale for mid-size regions. ${ }^{124}$ Mid-size central cities have to shift their scope of competition away from localities within their regions and towards other metropolitan regions.

After almost a century of the suburban sprawl, race and class stratification, environmentally harmful automobile dependence, and intra-regional local government competition that localism has produced, arguments in favor of fragmentation appear woefully short-sighted. While they contribute to a worthwhile debate about the impact of fragmentation on the economic competitiveness of a region, they pale in relevance to new insights about more sustainable regional governance structures. More innovative approaches characterized as "new regionalist" advocate for more centralized decision-making in an effort to limit regional inequities. ${ }^{125}$

Just as metropolitanization has redefined the meaning of urban and municipal identity, there have been concurrent shifts in the nature of economic development and metropolitan economic growth. The globalization narrative is now widely recognized and understood in its capacity for characterizing an array of dynamics that have become normalized in discussions about economics, culture, law, and

of communities the consumer voter has to choose from and the greater the variance between them, the closer the consumer will come to realizing his preference position, leading more local governments into intra-urban competition to provide the most competitive mix of taxes and services); Gillette, supra note 16 (arguing that the expansion of jurisdictional boundaries through annexation and regionalization threatens the benefits of decentralization, impairs the ability of smaller jurisdictions to promote political participation, and reduces the competition among localities to control bureaucratic budgets and facilitate monitoring of local officials).

${ }^{123}$ See Briffault, supra note 2, at 77-81.

${ }^{124}$ See, e.g., Nicole Stelle Garnett, Suburbs as Exit, Suburbs as Entrance, 106 MiCH. L. REV. 277, 29698 (2007) (discussing the negative externalities, transactional costs and related efficiency-based arguments against fragmentation).

${ }^{125}$ See, e.g., Nicole Stelle Garnett, Unsubsidizing Suburbia: The Urban Origins of Suburban Autonomy, 90 MinN. L. REV. 459, 484-86 (2005) (book review). 
society. ${ }^{126}$ The globalization of commerce, the financialization of the global economy, and the rise of multi-national corporations have spurred development and investment activities unrestricted by national borders or abstract notions of locational identity. ${ }^{127}$ This has spurred a growing attention to regional economies and policies. The processes of globalization express themselves in social and economic conditions of specific geographic regions, reshaping economies and urban spaces alike. ${ }^{128}$

Companies are increasingly brokering with local governments to secure the best deals for corporate headquarters and industrial plant locations, real estate development projects, and other investments. ${ }^{129}$ Capital mobility encompasses an ever-complexifying web of multi-national corporations, placeless enterprises, and the whimsical and self-serving economic values of a global elite whose

${ }^{126}$ See, e.g., Thomas L. Friedman, The World is Flat (2005); Joseph E. Stiglitz, Globalization AND ITS DisconTENTS (2002); David S. Law, Globalization and the Future of Constitutional Rights, 102 Nw. U.L. Rev. 1277 (2008); David Wilson, Globalization and the Changing U.S. City: Preface, 551 AnNals AM. ACAD. POL. \& SOC. SCI. 8 (1997).

${ }^{127}$ See, e.g., Yishai Blank, Federalism, Solidarity, and the Role of Local Governments in an Age of Global Multilevel Governance, 37 FORDHAM URB. L.J. 509, 513-16 (2010) (discussing the processes and characteristics of globalization and its subjective identification and social configuration).

${ }^{128}$ All are not convinced that globalization is an ominous harbinger of the economic fate of metropolitan regions. Some scholars have critiqued the mobility of capital narrative and exposed the manner in which it is, in many ways, a social construction deployed to justify local actions that often threaten the status of vulnerable communities. Specifically, the globalization trope has been presented as one that unleashes anxieties among businesspeople and policy makers and heavily influences the actions of people, places, and institutions. These critiques are compelling and offer necessary critical counter-perspectives to the hegemonic narratives advanced and the anti-communitarian motives they may conceal. This author appreciates the constructedness of the globalization trope and its potential to legitimize policies and politics that further marginalize disfavored and disempowered populations in metropolitan regions. But it cannot be overlooked that the increasing mobility of capital is simultaneously a social construction and an observable, quantifiable fact. On the one hand, there is a socially constructed narrative of mobile capital that serves the interests of capital in creating anxiety in the political class and the justification for public subsidies for business. On the other hand, capital is, in actuality, much less bounded by geographic borders or local allegiances than ever before. In responding to the legitimate critique that the globalization trope - or the mobile capital trope, in the context of this author's presentation - is often served up to prop up business interests, here the issue is presented to bolster the position of the metropolitan regional governments that inevitably have to contend with this phenomenon. See generally David A. Wilson, Cities AND Race: America's New Black GHetto $49-69$ (2007); see also Neil Smith, New Globalism, New Urbanism, in SPACES OF NeOliberalism: Urban ReSTRUCTURING IN NORTH AMERICAN AND EUROPE 86-87 (Neil Brenner \& Nik Theodore eds., 2002) (discussing the increasing territorialization of production centering in extended metropolitan centers rather than larger geographic regions).

${ }^{129}$ See Richard C. Schragger, Cities, Economic Development, and the Free Trade Constitution, 94 VA. L. REV. 1091 (2008). 
manipulation of technology allows them to surf the globe in search of new markets to exploit. These entities are constantly rent-seeking for the best locational value. ${ }^{130}$

The problem of mobile capital is the problem of capital mobility and, ultimately, capital flight. ${ }^{131}$ Capital is not always a rational actor and may remain tied to a region because of history, relationships, or other non-economic factors. As technology and financialization in global markets become ever more sophisticated, however, firms will be less and less tied to any one geographic place. ${ }^{132}$

Local governments are inherently immobile, place-based enterprises that seek to leverage their natural and developed capital to improve their quality of life. Local government competition has traditionally been conceived of in intermunicipal, intra-regional terms that strive to resolve the relative strengths and weaknesses between different municipal governments within a particular region. Economist and scholar of local government Charles Tiebout is noted for his theory that increased fragmentation and intra-regional, inter-municipal competition is good for "consumer voters" who seek to maximize the government services they receive while minimizing the taxes they pay. ${ }^{133} \mathrm{He}$ and others posit that municipal fragmentation is actually a preferable metropolitan local government organizing strategy, as it allows individuals and firms to choose the local government that best reflects their tastes and needs. ${ }^{134}$

Other theorists have focused on the "city powerless" theme, arguing that cities are ultimately powerless because they cannot control either their political destiny,

${ }^{130}$ It is important to note that not all capital is highly mobile or mobile at all. Businesses whose production or raw materials needs are geographically based, or which require a specifically skilled labor pool, are tied to place in a manner that flips the city-business power dynamic presented herein. Technologically advanced, high-skilled, service-related, and knowledge-based jobs, however, typically pay better, are more stable, attract a more stable, upwardly mobile labor base, and are generally more mobile than industrial or manual-labor jobs.

${ }^{131}$ See, e.g., Schragger, supra note 8, at 488 (defining mobile capital as the problem of capital flight and as the driver of the law and politics of local government).

${ }^{132}$ See id. at 488-92 (discussing how urban theorists have long cited the city's dependence on mobile capital as its defining feature).

${ }^{133}$ See generally Tiebout, supra note 122.

${ }^{134}$ See, e.g., Edwards, supra note 14, at 123 (Intra-regional fragmentation allows businesses and residents to "vote with their feet" and ultimately reside in the community that best meets their tax and service preferences and needs. These arguments fall under "public choice theory," which is predicated on the belief that voters, politicians and bureaucrats are mainly self-interested and employs economic tools to deal with the traditional problems of political science.); Vincent Ostrom, Charles M. Tiebout \& Robert Warren, The Organization of Government in Metropolitan Areas: A Theoretical Inquiry, 55 AM. POL. SCI. REV. 831 (1961). 
due to their status as instrumentalities of the states, or their economic destiny, due to the nature of mobile capital. ${ }^{135}$ Unlike the mid-twentieth century geopolitical and geoeconomic realities, however, today's conditions see governments in a particular region no longer able to look only inward to comprehend the challenges to growth going forward. They must acknowledge that global inter-urban competition for mobile capital renders the furtherance of intra-regional municipal fragmentation counterproductive in the new competitive paradigm. ${ }^{136}$

The effect of capital attraction on metropolitan economic development approaches presents new challenges for prevailing notions of localism in metropolitan governance. ${ }^{137}$ The ability of metropolitan regions to collectively offer services and develop stable tax bases is inextricably related to how they fare in the global competition for new economic development opportunities. ${ }^{138}$ Municipal fragmentation is cumbersome for navigating today's geopolitical and geoeconomic realities and essentially pits localities, regions, and states against each other.

For instance, cities like Kansas City, Kansas, and Kansas City, Missouri, exist in the same metropolitan region. ${ }^{139}$ Over the past few years the two cities have been engaged in what many have called a "border war," with each state courting the other's businesses with relocation tax incentive packages. ${ }^{140}$ Of the fifty-three companies that have received state tax incentives to move into Kansas since the 2009 fiscal year, forty-five have been from Missouri. ${ }^{141}$

${ }^{135}$ See, e.g., PAul Peterson, City Limits (1981); Gerald Frug, The City as a Legal Concept, 93 Harv. L. REV. 1057 (1980); Briffault, supra note 2; Briffault, supra note 8, at 355-56.

${ }^{136}$ See Schragger, supra note 8 , at 483 (discussing how urban politics must invariably be in favor of mobile capital, and that more robust economic regulation must take place at a higher level of government).

${ }^{137}$ See Schragger, supra note 129; see also Frug, supra note 56, at 1761.

${ }^{138}$ See, e.g., Steven S. Kaufman, Regional Economies and the Constitutional Imperative of Economic Domain, 58 CASE W. RES. L. REV. 1199, 1205-07 (2008) (discussing the need for regional governmental reform to address economic development realities).

${ }^{139}$ The Kansas City, MO-KS Metropolitan Statistical Area is recognized by the United States Office of Management and Budget and, as of April 1, 2010, ranked twenty-ninth among the top 366 top metropolitan regions. See U.S. OfFICE OF MGMT. \& Budget, supra note 79.

${ }^{140}$ See A.G. Sulzberger, In War Between States for Jobs, Businesses Stand to Gain Most, N.Y. TIMES, Apr. 8, 2011, at A1.

${ }^{141} I d$. 
Similarly, South Dakota has for a long time run print and radio advertisements in Minnesota to recruit neighboring businesses. ${ }^{142}$ The specter of these interstate competitions reflects a disconnect between global developments in the inter-urban competition for mobile capital and the manner in which policy makers on the ground perceive both their role and the explanations for their threatened or stifled economic development fortunes. Both local governments and corporations are responding to these new realities in a manner that calls for a reexamination of long held notions of intra-regional local government relations and the purported virtues of having many separate and autonomous local governments within a metropolitan region. ${ }^{143}$ Municipalities within a metropolitan region can minimize fragmentation by capitalizing on the efficiencies of more centralized metropolitan systems of governance. ${ }^{144}$

Like metropolitanization, there is a race and class dimension to the rise of these new geoeconomic forces. The manner in which geoeconomic forces and economic development pressures affect local government resource allocation is evidence of the globalization of urbanism. ${ }^{145}$ In the United States, the past three decades have seen an increase in social stratification, impacting historically marginalized populations and emerging disfavored identity groups. These developments have been well documented and discussed in sociological and geographic analyses of urban life in the past many years ${ }^{146}$ and have occurred

\footnotetext{
${ }^{142} I d$.

${ }^{143}$ While competition for capital is widely accepted as a catalyst for shifting government priorities away from non-productive public spending and toward business-friendly investments, the underlying benefit and ultimate effect on government behavior is unclear. Some scholars view such competition as an incentive for better government, while others contend that competition leads to a race to the bottom and negative consequences for the competing localities. See Hongbin Cai \& Daniel Treisman, Does Competition for Capital Discipline Governments? Decentralization, Globalization and Public Policy, 95 AM. ECON. REv. 817, 828 (2005); see also Daniel Treisman, Decentralization and the Quality of Government (Nov.20, 2000) (unpublished manuscript), www.imf.org/external/pubs/ft/seminar/2000/fiscal/treisman.pdf.

${ }^{144}$ See, e.g., Kaufman, supra note 138 (calling for intra-regional partnerships, although not specifically listing annexation as a tool for developing those partnerships).

${ }^{145}$ The term "globalization of urbanism" has been used in a number of contexts, but always to describe the impact of globalism on the urban form, urban governance and urban culture. See, e.g., GLOBAL Cities: Cinema, Architecture and Urbanism in a Digital Age (Linda Krause \& Patrice Petro eds., 2003).

${ }^{146}$ See generally SCHWARTZ, supra note 48; WILSON, supra note 48; WILSON, supra note 128.
} 
concurrently with a rising anti-government backlash tied to post-Great Society and Civil Rights Era political conservatism. ${ }^{147}$

Urban geographer Neil Smith has used the term "revanchist city" to characterize the modern city's embrace of authoritarian forms of social control and considerable subsidies to corporate interests. ${ }^{148}$ Essentially, the globalization of urbanism is reflected in the manner that capital attraction motives have influenced local urban policy. These trends are linked to the rise of urban development regimes overly focused on affluent development and modified measures that facilitate segregation by economic class, real or perceived aspirational identity, and favored or disfavored identity status. In the context of these social and economic processes, annexation can serve as either a tool to facilitate the affluent suburbanite's separation or as a tool to facilitate the municipality's maintenance of redistributive economies and governance. ${ }^{149}$

${ }^{147}$ See, e.g., Alice O’Connor, Poverty Knowledge: Social Science, Social Policy and the POOR IN TWENTIETH CENTURY U.S. History 246-59 (2001) (discussing both the development of neoconservative rhetoric and neoliberalism that formed the new "welfare consensus" constructed around notions of the "deserving" and "undeserving" poor and the role of government in addressing their needs, specifically resulting in the dramatic decrease in social services and social welfare spending, particularly in monies dedicated for urban renewal, during the rise of modern conservatism in the Reagan era).

148 See generally NeIl Smith, The New Urban Frontier: Gentrification and the Revanchist CITY (1996). Revanchists (from the French word "revanche," meaning "revenge") were a group of Parisian bourgeois nationalist reactionaries who opposed the rise of liberalism when the working classes took over from the defeated government of Napoleon III and controlled the city for months. The revanchists were determined to reinstate the bourgeois order using a strategy that fused militarism and moralism with claims about restoring public order on the streets. Neil Smith identifies the similarities between the revanchism of late-nineteenth century Paris and the political climate of late-twentieth century New York City that emerged to fill the vacuum left by the disintegration of liberal urban policy. The notion of "the revanchist city" captures the disturbing urban condition created by a political shift from the redistributive liberal policy of the post-1960 era leading up to the 1980s and the revanchism that took hold afterwards. Whereas the liberal period was characterized by redistributive policy, affirmative action and antipoverty legislation, the era of neoliberal revanchism was characterized by a discourse of revenge against minorities, the working class, feminists, environmental activists, gays and lesbians, and recent immigrants: the "public enemies" of the bourgeois political elite and their supporters. New York City in the 1990s became an arena for concerted attacks on affirmative action and immigration policy, street violence against gays and homeless people, feminist-bashing, and public campaigns against political correctness and multiculturalism. Just as the bourgeois order was perceived as under threat by the revanchists of 1890s Paris, in 1990s New York, a particular, exclusionary vision of "civil society" was being reinstated with a vengeance - an attempt to banish those not part of that vision to the urban periphery. Smith expanded his revanchism theory to something common to the restructured urban geography of the late capitalist city.

${ }^{149}$ See, e.g., Anderson, supra note 16, at 944-59. 
The urban/suburban frame fails to comprehend and adequately characterize metropolitanization in mid-size regions, and its value diminishes even further in the face of emerging trends in urban redevelopment, new urbanism, ${ }^{150}$ gentrification, and the banishment of the urban poor and working poor. These economic realignments influence land use and development patterns to focus on spaces that fit the commodified, mass-marketed, idealized aesthetic of mixed-use (and seldom mixed-income), master-planned community living and those spaces that do not. ${ }^{151}$ These developments have transformed the contemporary landscape of urban development into what has been called "a highly commodified arena of urban place production." 152

The most typical way of intensifying land use is growth, which usually expresses itself in a constantly rising population. Cities promote their "good business climate" attributes, which include low business taxes, a good infrastructure of municipal services, vigorous law enforcement, an eager and docile labor force, and a minimum of business regulations. An expanded work force and its attendant purchasing power, in turn, lead to an expansion of retail and other commercial activity, extensive land and housing development, and increased financial activity. This chain of events and its consequences renders the city a "growth machine," and those who dominate it, members of a "growth coalition."153

${ }^{150}$ New Urbanism is the more than twenty-year-old architectural and urban-planning movement that advocates and promotes the development of mixed-use (and, in some cases mixed-income, but not necessarily), walkable neighborhoods and developments that minimize automobile dependence and wasteful land use while maximizing density, master planning, and compactness. New Urbanism has also led the development of smart codes, which codify new urbanism principles and approaches into implementable zoning and land-use policies. Smart codes are developed in a manner that is easily adaptable for municipal governments. For a further discussion of new urbanism, see generally Michael Lewyn, New Urbanist Zoning for Dummies, 58 ALA. L. REV. 257 (2006).

${ }^{151}$ See Briffault, supra note 8, at 383-90 (discussing legal and policy developments supporting exclusionary zoning in suburban communities).

152 The Urban Growth Machine: Critical Perspectives Two Decades Later 6 (Andrew E.G. Jonas \& David Wilson eds., 1999) [hereinafter THE URBAN GRowth MACHINE].

${ }^{153}$ The "growth machine" thesis argues that central to urban politics is land and its political, economic, and social construction as place. The thesis focuses around coalitions of land-based elites, united around the commodification and related economic-centric construction of the possibilities of place, who drove urban politics in their quest to expand the local economy and accumulate wealth. "Growth coalition theory" posits that city governments are, in many ways, local power structures representing an aggregate of land-based interests that profit from the increasingly intensive use of land. Property owners see their futures as linked together because of a common desire to increase the value of their individual parcels. See, e.g., Scott Rogers \& Milton Keynes, Urban Geography: Urban Growth Machine, in 12 INT'L ENCYCLOPEDIA Hum. GEOGRAPHY 40, 40-45 (Rob Kitchin \& Nigel Thrift eds., 2009). See John R. Logan \& Harvey. L. Molotch, Urban Fortunes: The Political Economy of Place (1987). See also THE URBAN GROWTH MACHINE, supra note 152. 
U N I V E R S I T Y O F P I T T S B U R G H L A W R E V I E W

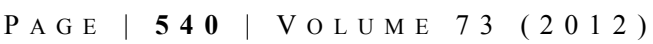

While in many ways these dynamics have always been present in cities and are understandable given the structure of American capitalism, recent geoeconomic shifts have intensified their character, such that these dynamics now dominate local political economy. ${ }^{154}$

The "growth machine" thesis reflects other critical perspectives on urban governance and political economy that essentially mobilize urban space for economic growth and to cater to the consumption practices and tastes of the affluent. ${ }^{155}$ Casting these developments as entirely negative is too simplistic of an analysis, for there are benefits and challenges presented by the new arrangements and institutional realignments that can be managed for egalitarian purposes. For this to occur, however, central cities must be able to expand their borders in a manner that allows them to exercise the economic development leadership necessary to succeed amidst the broader terrain of inter-urban competition for mobile capital. ${ }^{156}$

Global capitalist growth and expansion-particularly for the firms that characterize mobile capital - is tied to geographic landscapes through a process that privileges some places, territories, and regions as sites for capital accumulation to the detriment of others. ${ }^{157}$ These geoeconomic shifts and transformations are altering the connections between transnational capital, social relations, and the meaning of "community," "urban," and "regional."158 Restrictive annexation regimes can limit a city's ability to grow, thereby making annexation policy a concern of great significance to mid-size metropolitan regions.

\footnotetext{
${ }^{154}$ See Schragger, supra note 8, at 491-97 (discussing the history of boosterism, growth coalitions and the politics of capital attraction).

${ }^{155}$ See Neil Brenner \& Nik Theodore, Cities and the Geographies of "Actually Existing Neoliberalism," in SPACES OF NeOliberalism: Urban Restructuring IN NORTH AMERICA AND WeStERn Europe 2, 20-29 (Neil Brenner \& Nik Theodore eds., 2002).

${ }^{156}$ Benefits include the establishment of cooperative, business-led networks in local politics; the mobilization of new forms of local economic development policy that foster inter-firm cooperation and industrial clustering; the development of community-based programs to alleviate social exclusion; the promotion of new forms of coordination and inter-organizational networking among previously distinct spheres of local and state intervention; and the creation of new regional institutions to promote metropolitan-wide place-marketing and intergovernmental coordination. See id. at 27.

${ }^{157}$ See id. at 2-32.

${ }^{158}$ See Smith, supra note 128 , at $80-103$.
} 


\section{PART III: ANNEXATION IN CONTEXT: APPROACHES AND SOLUTIONS}

A central city's boundary expansion plans not only have to contend with the myriad of factors driving central city out-migration, but also its state's annexation regime. Research shows that there is a relationship between a state's annexation regime and the nature of annexation activity in the state. ${ }^{159}$ If taxes or race and class dynamics have driven high-tax residents to unincorporated areas on the central city's periphery, the state's annexation regime can aid the central city in recapturing that tax base; such recapture efforts are typically the impetus for contentious annexation battles. While these annexation battles occur frequently, Mississippi, Tennessee, and North Carolina provide compelling examples for how state annexation regimes can either help or hinder mid-size central cities.

These states differ considerably in both the theory of annexation they embrace and the construction of their respective annexation regimes, but they are alike in that they are all Southern states whose largest metropolitan regions fall within this author's definition of mid-size. ${ }^{160}$ Many of their regional central cities have been actively and frequently pursuing growth objectives that include or are dependent upon annexation. ${ }^{161}$

Size matters for the mid-size central cities of these states. They have expanded through previous annexations and, in many cases, have tested their states' annexation laws through prolonged, intense boundary disputes. While metropolitanization has forged strong regional identities, opposition to annexation persists. What mediates the impact of this annexation backlash is the relative sophistication of the state's respective annexation regime. For Jackson, Mississippi, the state's annexation policy has effectively stifled its expansion. Tennessee's annexation regime includes a land use policy with meaningful protections of central cities. North Carolina's annexation regime has arguably fueled the considerable economic development successes of metropolitan regions throughout the state.

\footnotetext{
${ }^{159}$ See Edwards, supra note 14, at 125-27.

${ }^{160}$ The population numbers and rankings for the mid-size MSAs of the three states are: Charlotte, North Carolina (1.7 million; 33); Nashville, Tennessee (1.59 million; 38); Memphis, Tennessee (1.3 million; 41); Raleigh, North Carolina (1.13 million; 48); Greensboro, North Carolina (723,801; 71); Knoxville, Tennessee (698,030; 75); Jackson, Mississippi $(539,057$; 96); Chattanooga, Tennessee $(528,143 ; 97)$ and Durham, North Carolina (504,357; 102). See U.S. OfFICE OF MGMT. \& BUdGET, supra note 79.

${ }^{161}$ See generally Rice, supra note 53.
} 
U N I V E R S I T Y O F P I T T S B U R G H L A W R E V I E W

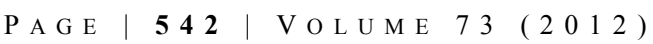

\section{A. Mississippi}

Disputes over the expansion of Mississippi's largest city, Jackson, illustrate the challenges mid-size central cities face in resolving weak state annexation regimes with the need for boundary expansion. Jackson is the ninety-sixth largest metropolitan region in the nation and grew $8.42 \%$ between 2000 and $2010 .{ }^{162}$ It is the largest metropolitan region in the state of Mississippi and is the state capital. Jackson is characteristic of many mid-size regions. Its land use patterns are characterized by low to moderate-density development over a relatively territorially compact urbanized area with a patchwork of suburbs and rural development on the periphery. The urban form is dominated by the roadways and parking lots that facilitate automobile movement within and through the region. Race and class dynamics reflect high levels of stratification, while attractive options for white and middle-class flight outside of the central city largely consist of neighborhoodcentric residential development with supporting retail and commercial developments in a rural or light-suburban setting.

The recently incorporated town of Byram, Mississippi, lies immediately on Jackson's southern boundary. ${ }^{163}$ For more than ten years, Byram was embroiled in legal battles with Jackson regarding its annexation and incorporation. ${ }^{164}$ The first round occurred in the 1990s when Byram successfully defeated an attempted annexation of its area. The case of In re Enlargement and Extension of the Municipal Boundaries of Jackson (Byram I) ${ }^{165}$ arose out of Jackson's attempted annexation of 24.25 square miles of unincorporated territory that included Byram. ${ }^{166}$ Pursuant to the state's annexation policy, the Jackson City Council adopted an ordinance approving the annexation, the petition was filed in the Chancery Court, and final judgment was rendered in favor of the City of

\footnotetext{
162 State of Metropolitan America Indicator Map, BROOKINGS InST., www.brookings.edu/metro/ StateOfMetroAmerica/Map.aspx\# (last visited Oct. 18, 2012).

163 See Cheryl Lasseter, Byram Is Soon To Be an Incorporated City, WBLT (Apr. 3, 2009), http://www.wlbt.com/global/story.asp?s=10129297.

164 See, e.g., Elizabeth Kirkland, Byram Community Seeking Incorporation Again, Miss. BUS. J., May 28, 2001, at 15.

${ }^{165} 691$ So. 2 d 978 (Miss. 1997).

${ }^{166}$ See id. at 979.
} 
Jackson. ${ }^{167}$ The action was approved by the lower court but ultimately overturned by the Mississippi Supreme Court. ${ }^{168}$

Jackson's ability to annex the Byram area was greatly limited by Mississippi's annexation regime. Mississippi’s statutes relating to municipalities contain no policy statements on the role of annexation and incorporation in landuse planning. ${ }^{169}$ Procedurally, Mississippi allows for a municipality seeking to annex unincorporated lands to initiate the matter in its governing body. If passed, the municipality must present the petition to the Chancery Court of its county. ${ }^{170}$ The statute provides that the Chancery Court should ratify the petition if the annexation is reasonable and is required by public convenience and necessity. ${ }^{171}$ Under Mississippi law the courts are charged with assessing the reasonableness of a municipality's decision to annex unincorporated property. ${ }^{172}$ Mississippi courts have determined that annexation is reasonable only if it is fair and that, in making this determination, annexation must be viewed from the perspective of both the city and the landowners of the proposed annexation area. ${ }^{173}$

Mississippi courts have established twelve indicia against which the reasonableness of a particular annexation proposal is judged. ${ }^{174}$ The courts consider

\footnotetext{
${ }^{167}$ See id.

${ }^{168}$ See id. at $979-80$.

${ }^{169}$ See Miss. Code ANN. § 21-1-27 (2011).

${ }^{170}$ See id. § 21-1-29.

${ }^{171}$ See id. $\$ 21-1-33$ ("If the chancellor finds from the evidence presented at such hearing that the proposed enlargement or contraction is reasonable and is required by the public convenience and necessity and, in the event of an enlargement of a municipality, that reasonable public and municipal services will be rendered in the annexed territory within a reasonable time, the chancellor shall enter a decree approving, ratifying and confirming the proposed enlargement or contraction, and describing the boundaries of the municipality as altered.”).

${ }^{172}$ See City of Jackson v. Byram Incorporators, 16 So. 3d 662, 672 (Miss. 2009) ("The authority to initiate such [annexation] proceedings rests with the governing authorities of such municipality.").

${ }^{173}$ See generally Byram I, 691 So. $2 \mathrm{~d} 978$.

${ }^{174}$ See, e.g., id. at 980 (citing In re Extension of the Boundaries of Jackson, 551 So. 2d 861, 864 (Miss. 1989)). The twelve indicia of reasonableness are (1) the municipality's need to expand; (2) whether the area sought to be annexed is reasonably within a path of growth of the city; (3) potential health hazards from sewage and waste disposal in the annexed areas; (4) the municipality's financial ability to make the improvements and furnish municipal services promised; (5) need for zoning and overall planning in the areas; (6) need for municipal services in the areas sought to be annexed; (7) whether there are natural barriers between the city and the proposed annexation area; (8) past performance and time element involved in the city's provision of services to its present residents; (9) economic or other impact of the annexation upon those who live in or own property in the proposed annexation area; (10) impact of the
} 
these factors under a totality of the circumstances analysis that limits the ability of any one factor to be considered separately or independently of the others. ${ }^{175} \mathrm{In}$ Byram I, Jackson framed its argument in regionalist terms by contending that the fate of the region was directly tied to the success of its central city, Jackson. It argued that a decline in its general welfare, quality of life, or economic development potential would have an adverse effect not only on Jackson but on the entire metropolitan region. ${ }^{176}$ Additionally, the city argued that it needed to expand its tax base to deal with declining real property values and stagnant municipal tax revenue. ${ }^{177}$ The lower court was sympathetic to this position, holding that as the economic, governmental, and cultural center of the state, Jackson's continued economic well-being is important to the central portion of Mississippi and the entire state. ${ }^{178}$ The lower court's conception of reasonableness incorporated an analysis of the economic development impact on the region as opposed to just a narrow consideration of the localist concerns of the Byram residents.

The Mississippi Supreme Court disagreed, however, and sided with Byram area residents rather than Jackson's growth and economic development realities. Ultimately, the Mississippi Supreme Court deemed the annexation a "tax grab," unreasonable and unfair to the residents of the proposed annexation area. ${ }^{179}$ In a dissenting opinion, however, state Supreme Court Judge Prather defended Jackson's position and built upon the lower court's argument for a regionalist frame in applying the court's reasonableness standard.

Judge Prather recognized the importance of Jackson to the region and that its decline would have an adverse effect on the entire metropolitan region, including the proposed annexation area. ${ }^{180}$ His dissent displayed a keen awareness of the irony present in the Byram residents' arguments, stating, "I find it ironic that

\footnotetext{
annexation upon the voting strength of protected minority groups; (11) whether the property owners and other inhabitants of the areas sought to be annexed have in the past, and in the foreseeable future unless annexed will, because of their reasonable proximity to the corporate limits of the municipality, enjoy economic and social benefits of the municipality without paying their fair share of taxes; and (12) any other factors that may suggest reasonableness. Id. at 980.

${ }^{175}$ See, e.g., Magnolia Marine Transp. v. City of Vicksburg, 560 So. 2d 713 (Miss. 1990).

${ }^{176}$ See Byram I, 691 So. 2 d at 983.

${ }^{177}$ See id. at 984 (Prather, J., dissenting).

${ }^{178}$ See id. at 988 (Prather, J., dissenting).

${ }^{179}$ See id. (Prather, J., dissenting).

${ }^{180}$ See id. at 990 (Prather, J., dissenting).
} 
representatives of areas which have grown largely out of a desire to avoid taxation for the services which they enjoy in City of Jackson should accuse the City of attempting a 'tax grab' out of considerations of greed."181 Judge Prather reminded the court that it was departing from its previously expressed concerns for the regional impacts of Jackson's decline. In the earlier case of In re Extension of Boundaries of Jackson, ${ }^{182}$ the Mississippi Supreme Court found in favor of Jackson's annexation proposal by interpreting Jackson's long-range growth prospects as fitting the definition of its first index of reasonableness: the municipality's need to expand. ${ }^{183}$ Judge Prather included in his dissent the court's statement in that case that

Jackson's need for an expanded tax base is reasonable as well. As a matter of fact, recent years reflect a gradual recession of Jackson's (economic) life blood to the various surrounding communities. These communities have experienced meteoric growth, most of them with a planned development. They have drained off and continue to drain off the life of the city's flow of wealth in people, culture and dollars. Indeed, the very statistics recited by the Court below are the product of the flight of so many persons from Jackson's corporate limits, not so far as to deprive themselves of full access to the economic, social and cultural benefits Jackson has to offer but only so far as to sever their relationship with Jackson's assessor and tax collector. Barring a wholly unanticipated act of altruism by Ridgeland, Madison, Flowood, Pearl, Richland, Florence or Clinton - not to mention unincorporated western Rankin County, Jackson faces the certainty of a slow but sure erosion of its tax base by the unilateral actions of these selfish former citizens. ${ }^{184}$

The Byram residents had legitimate concerns about Jackson's ability to manage service delivery in the area proposed for annexation. The testimony presented in the case revealed that Jackson had arguably underperformed in the management of its resources. ${ }^{185}$ Jackson's image as being worthy of the right to annex additional areas was also dogged by its past failure to furnish promised

${ }^{181}$ See id. at $988-89$.

182551 So. 2 d 861 (Miss. 1989).

${ }^{183}$ See id. at 865 .

${ }^{184}$ See Byram I, 691 So. 2d at 988 (Pranther, J., dissenting).

${ }^{185}$ See id. at 984 (discussing the testimony of the objectors' expert who testified that the case represented the only instance where he found a county level of service in terms of street and right-ofway maintenance that was noticeably better than that within the city). 
U N I V E R S I T Y O F P I T T S B U R G H L A W R E V I E W

PAGE

improvements to areas annexed in 1976 and $1989 .{ }^{186}$ Several objective criticisms of Jackson's ability to service additional areas were presented, and a common thread in state annexation regimes is the requirement that the annexing municipality be capable of extending its infrastructure and public services into an annexed area. ${ }^{187}$ But service delivery concerns are incidental to broader considerations of regional interdependence and a social construction of municipal boundaries that ultimately pits communities within a region against each other.

The 1997 Byram case was act one in the saga for Jackson's expansion. In 2009, the Mississippi Supreme Court again addressed the issue of Jackson's expansion into the Byram area in City of Jackson v. Byram Incorporators (Byram II). ${ }^{188}$ The matter involved the combined case of the incorporation petition of the Byram area residents and another annexation petition by the City of Jackson. The "Byram Incorporators," as the court referred to them, were attempting to incorporate Byram at the same time as Jackson was trying again to annex an area that included Byram. With regard to the annexation petition, the court again looked to its twelve indicia of reasonableness, considering each of them individually. The first factor is the city's need for expansion. ${ }^{189}$ Within this specific category, the court has enumerated additional factors for consideration, including spillover development into the proposed annexation area, the municipality's internal growth, the need to expand the municipality's tax base, and limitations due to geography and environmental influences, among others. ${ }^{190}$

Jackson asserted that its 2002 population density of $1,724.27$ residents per square mile was high in relation to other Southern cities and that it only had fifteen to twenty percent vacant, developable land within its city limits. ${ }^{191}$ The court's consideration of the city's need to expand involved judgments on whether the city's density afforded it enough land for future growth and whether the need for increased tax revenues was proportional to the size of the area the city sought to annex. ${ }^{192}$ Based on this analysis, the court upheld the lower court's reduction in the

\footnotetext{
${ }^{186}$ See id.

${ }^{187}$ See id.

188 16 So. 3d 662, 672 (Miss. 2009).

${ }^{189}$ See id. at $683-84$.

${ }^{190}$ See id.

${ }^{191}$ See id. at 684.

${ }^{192}$ See id. at 684-85.
} 
proposed area for annexation to what it considered to be in direct proportion with the city's need to expand. ${ }^{193}$

It is likely that Jackson's arguments in the case limited the court's consideration of the more significant growth considerations the court had previously acknowledged. ${ }^{194}$ Jackson's arguments were more inwardly focused; they failed to adequately communicate the city's position within a larger metropolitan region or the challenges its mid-size status presents for future economic development endeavors. Jackson argued that it was too dense, an argument that runs counter to the anti-sprawl logic that would also oppose regional fragmentation. ${ }^{195}$ While the city's relative density is certainly informative for understanding land use patterns, it is less relevant in assessing how boundary expansion will enhance the economic health and competitive profile of not just Jackson, but the entire region. The city's need for increased revenue is a more useful measurement, but even this factor requires context to have an impact. If the "need for increased revenue" justification for annexation is viewed in a zero-sum light where, in order for the city to win, the proposed area for annexation must lose, it loses its persuasiveness given the cultural draw of local autonomy in local government law.

The "need for increased revenue" justification for annexation must be viewed in regionalist terms, which recasts annexation as a win-win scenario in which the annexed area benefits from the improved economic position of the central city. The court's analysis in both cases fails to conceptualize Jackson as the economic development anchor for the areas both within and outside its borders. The court seems committed to viewing the factors impacting Jackson's fate as being contained by its municipal boundaries as opposed to spilling over into the metropolitan region.

Considering the judiciary's primary function of dispute resolution within the context of the facts of a particular controversy, broader questions about urban policy and the externalities associated with municipal boundary reformations should be determined by the legislature. With no guiding philosophy on the role of local government expansion as related to a broader urban policy concern, Mississippi has abdicated these important urban policy and economic development matters to the litigation process. Of the twelve indicia of reasonableness the

\footnotetext{
${ }^{193}$ See id.

${ }^{194}$ See supra note 183 and accompanying text.

${ }^{195}$ See Byram II, 16 So. $3 \mathrm{~d}$ at 684.
} 
U N I V E R S I T Y O F P I T T S B U R G H L A W R E V I E W

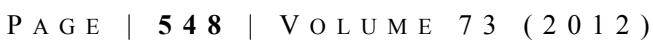

Mississippi court deploys in reviewing challenges to municipal annexation, none of them directly addresses the prosperity of the metropolitan region.

Recently, Jackson and Byram's home county, Hinds County, embarked on a county-wide economic development marketing effort geared toward promoting the county as a whole. ${ }^{196}$ Developments like these signal that the Jackson metropolitan regional stakeholders are aware of their interdependence. In its 2010 annual report, Jackson reported a Moody's bond rating of Aa2, which is relatively high. ${ }^{197}$ This strong financial indicator, in light of past boundary issues, runs contrary to Rusk's thesis. It is likely, however, that Jackson's relatively low regional growth rate between the 2000 and 2010 census reflects the consequences of entrenched fragmentation. ${ }^{198}$

\section{B. Tennessee}

Tennessee's annexation statute differs considerably from Mississippi's in both its procedural development and its expression of the role of annexation in municipal economic health and growth. Tennessee's annexation statute provides, in relevant part, that an annexation will be deemed necessary not only when a majority of residents and property owners in the affected area present a petition, but also when it appears the "prosperity of the municipality will be materially retarded" without the annexation. ${ }^{199}$ This choice of statutory language implicitly recognizes the need for cities to expand and privileges those needs in a manner that could potentially outrank the will of private individuals to remain outside a particular city's boundaries. This disposition bodes well for the cities and mid-size regions like Memphis and Nashville that are, to varying degrees, globally recognized for their cultural and historical assets but are still vying for competitive positioning with larger regions. ${ }^{200}$

Tennessee's annexation statute explicitly favors the growth of its largest municipalities by affording them priority in annexation contests. Where two

\footnotetext{
${ }^{196}$ See Ruth Ingram, Marketing Message Unveiled for Hinds, CLARION LEDGER, July 22, 2011, at B1.

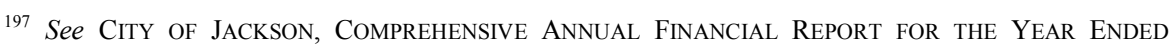
SEPTEMBER 30, 2010, at iv (2010).

${ }^{198}$ See supra note 162 and accompanying text.

${ }^{199}$ See TENN. CodE ANN. § 6-51-102 (2011).

${ }^{200}$ For a general resource on Tennessee's economic development strivings, see G. Mark Mamantov, Abating Property Taxes in Tennessee: An Essential Tool in the Economic Development Toolbox, 4 TRANSACtions: TENN. J. Bus. L. 89 (2003) (discussing methods of economic development within Tennessee).
} 
municipalities incorporated in the same county seek to annex the same territory, the proceedings of the municipality having the larger population will have precedence and the smaller municipality's proceedings will be held in abeyance pending the outcome of the proceedings of the larger municipality. ${ }^{201}$ Essentially, size matters in Tennessee's annexation regime, and the state has determined that it wants to privilege those municipalities that, by virtue of scale, are likely best suited for continued growth and expansion.

Tennessee's current annexation statute is the result of the invalidation of a 1997 annexation law that made it easier for small towns located on the urban fringe areas adjacent to larger cities to incorporate themselves rather than be annexed by the region's central city. ${ }^{202}$ The 1997 law was struck down by the Tennessee Supreme Court in Tennessee Municipal League v. Thompson, ${ }^{203}$ after which the state legislature created a committee to rewrite the annexation law. ${ }^{204}$ The new annexation statute was hailed as a progressive step forward. ${ }^{205}$ It resulted in a broader Growth Management Law that had as its stated purpose "to direct the coordinated, efficient and orderly development of the local government and its environs that will, based on an analysis of present and future needs, best promote the public health, safety, morals, and general welfare." ${ }^{206}$ The Growth Management Law (commonly referred to as the "Growth Policy Act") directs each city and county to determine an urban growth boundary to guide its development. ${ }^{207}$

\footnotetext{
${ }^{201}$ See, e.g., TENN. CODE ANN. § 6-51-110(b).

${ }^{202}$ See 1997 Tenn. Pub. Acts, ch. 98; Tenn. Mun. League v. Thompson, 958 S.W.2d 333, 334-35 (Tenn. 1997) (discussing the background and construction of the annexation statute); Michael J. Stewart, Growth and Its Implications: An Evaluation of Tennessee's Growth Management Plan, 67 TenN. L. REV. 983, 987 (2000) (discussing the origins of Tennessee's Growth Management Law and its relation to the state's annexation statute).

${ }^{203} 958$ S.W.2d 333 (Tenn. 1997).

${ }^{204}$ Stewart, supra note 202, at 987 . Among other things, the 1997 annexation law significantly lowered the population requirement for the incorporation of a municipality, deleted prohibitions on the incorporation of new municipalities within certain distances of existing municipalities of a certain population, and allowed a letter from a single resident to be used in lieu of a petition to incorporate a new municipality without requiring submission of a plan for municipal services or a five year budget. See Thompson, 958 S.W.2d at 334-35.

${ }^{205}$ See Stewart, supra note 202, at 987-88 (2000) (discussing the passage of Tennessee's Growth Management Law and its reception in the national planning community).

${ }^{206}$ See id. at 987-91; TENN. CODE ANN. § 6-58-107.

${ }^{207}$ See TENN. CODE ANN. § 6-58-104(a).
} 
One of the aims of the Growth Policy Act is to eliminate the incorporation of unincorporated areas driven by the fear of being annexed by the central city, or what is known as defensive incorporation. ${ }^{208}$ Under the Growth Policy Act, a municipality possesses exclusive authority to annex territory located within its approved urban growth boundaries; therefore, no municipality may annex by ordinance or referendum any territory located within another municipality's approved urban growth boundaries. ${ }^{209}$ The combined effect of Tennessee's annexation statute and its Growth Policy Act statue incentivizes urban growth planning by tying a municipality's annexation powers to the development of its growth plan. $^{210}$

Tennessee's regard for the growth and prosperity of its municipalities is not only codified in the statutory language, but also in Tennessee courts' interpretations of the annexation statute. Tennessee courts recognize a fairly limited level of judicial review in annexation cases, holding that annexation is a legislative matter that will not be disturbed by the court on review unless the legislative will can be shown to be arbitrary and unreasonable. ${ }^{211}$ In assessing whether an annexation is reasonable, Tennessee courts have acknowledged that there are always advantages and disadvantages to annexation, but ultimately if the court finds the advantages

${ }^{208}$ See id. § 6-58-102(1)-(5). For a broader discussion of defensive incorporation, see Garnett, supra note 125 , at $285-87$.

${ }^{209}$ TenN. CODE ANN. § 6-58-111(a).

${ }^{210}$ See id. ("Within a municipality's approved urban growth boundaries, a municipality may use any of the methods in chapter 51 [the annexation statute] of this title to annex territory; provided, that if a quo warranto action is filed to challenge the annexation, the party filing the action has the burden of proving that: (1) An annexation ordinance is unreasonable for the overall well-being of the communities involved; or (2) The health, safety, and welfare of the citizens and property owners of the municipality and territory will not be materially retarded in the absence of such annexation.").

${ }^{211}$ See, e.g., State ex rel. Hicks v. City of Chattanooga, 513 S.W.2d 780, 783 (Tenn. 1974). Tennessee's annexation statute makes no provision for judicial review of annexations approved by a referendum vote. See, e.g., TENn. CODE ANN. §6-51-104(a) ("A municipality, when petitioned by interested persons, or upon its own initiative, by resolution, may propose extension of its corporate limits by the annexation of territory adjoining to its existing boundaries."); State ex rel. Vicars v. City of Kingsport, 659 S.W.2d 367, 369 (Tenn. Ct. App. 1983) ("Our annexation statutes expressly permit a court review when the method of annexation is by adoption of an ordinance but make no provision for court review when annexation is by referendum. Presumably, the legislature recognized that the citizens of the territory being annexed had no right of action in one method and did have a right to action in the other .... The court is of the opinion that there can be no judicial review of plaintiffs' suit under T.C.A. 6-51103 (the reasonableness test) as such procedures only apply to annexation by ordinance cases. However, the court finds that the allegations of the complaint averring constitutional defects and infirmities in the adoption of the resolution and/or the election by referendum is reviewable."). 
and disadvantages of the annexation to be debatable, then it must rule in its favor. $^{212}$

In State ex rel. Collier v. Pigeon Forge, ${ }^{213}$ a case challenging the reasonableness of an annexation ordinance, the Tennessee Supreme Court held that the applicable test for determining whether an annexation is proper requires the consideration of all factors with the primary focus being on whether the ordinance was reasonable for the planned and orderly growth of the city. ${ }^{214}$ Pigeon Forge involved the annexation of an area lying in the growth pattern of Pigeon Forge, a small tourist-oriented city located in the foothills of the Smoky Mountains thirty miles Southeast of Knoxville. ${ }^{215}$ Pigeon Forge is several miles south of Sevierville, which is considered part of the Knoxville metropolitan region, the seventy-fifth largest MSA. ${ }^{216}$

In reviewing the Pigeon Forge annexation, the court took into consideration its justifications for expansion, namely the need to guard against a "helter-skelter" development of commercial activities that may not be in harmony with those already in operation. ${ }^{217}$ The court even went so far as to state that the failure of a city to extend its corporate boundaries to embrace contiguous areas of growth and development is an abdication of its responsibility. ${ }^{218}$ In arriving at its decision to uphold the annexation, the court reviewed its previous statements on its theory of annexation. The court reaffirmed its contention that the appropriate theory of annexation recognizes it as a device by which a municipality may plan for its

\footnotetext{
${ }^{212}$ See, e.g., State ex rel. Hicks, 513 S.W.2d 780 at 783.

${ }^{213} 599$ S.W.2d 545 (Tenn. 1980).

${ }^{214}$ See id. at 548 .

${ }^{215}$ See id. at 546.

${ }^{216}$ See U.S. OfFICE OF MgMt. \& Budget, supra note 79. While Pigeon Forge is likely considered to be within the official Knoxville metropolitan statistical area, the Pigeon Forge case casts it as the "central city," in the parlance of this article.

${ }^{217}$ State of Tenn. ex rel. Collier, 599 S.W.2d at 547.

${ }^{218}$ See id. ("[Annexation] has a vital concern in guarding against the helter-skelter establishment of commercial activities that may not be in harmony with those already in operation. Indeed, the prevention of incompatible commercial enterprises is a high municipal duty. The failure of a city to extend its corporate boundaries to embrace contiguous areas of growth and development is an abdication of responsibility. The time to annex is in the incipient stage of growth, lest the basic purpose of annexation be frustrated and the public interest suffer by the annexation of substandard areas.").
} 
U N I V E R S I T Y O F P I T T S B U R G H L A W R E V I E W

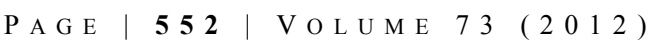

orderly growth and development in a manner that "gives the city some control over its destiny."219

Tennessee courts have wrestled with challenges to the legitimacy of annexation efforts brought by those living in areas proposed for annexation. While Memphis, Tennessee, is neither the state's capital nor its largest metropolitan region, it is arguably the state's most renowned and symbolic metropolitan region. $^{220}$ Memphis ranks second in population behind Nashville, the MSAs ranking numbers forty-one and thirty-eight, respectively. ${ }^{221}$ In Vollmer $v$. Memphis, ${ }^{222}$ the Tennessee Supreme Court's reasonableness analysis incorporated factors affecting both the welfare of the affected residents and property owners, as well as the welfare of the municipality as a whole. ${ }^{223}$

Vollmer involved a challenge to the reasonableness and constitutionality of an annexation ordinance brought by residents living in the area proposed for annexation. $^{224}$ The court recognized that the annexation would place the affected citizens of the area on the tax rolls of Memphis, allowing them to pay for services they enjoy without cost, including parks, libraries, and public facilities financed and provided by the city. ${ }^{225}$ The court also took into consideration that the great majority of the residents in the affected area were employed in Memphis and commuted to Memphis in automobiles which did not then meet the emission standards required of automobiles owned by Memphis residents, surmising that compliance with the higher Memphis standards would ensure cleaner air for

${ }^{219}$ See id. (citing City of Kingsport v. State ex rel. Crown Enters., 562 S.W.2d 808, 814 (Tenn. 1978)).

${ }^{220}$ Located on the Mississippi River, Memphis is internationally renowned as the home of Graceland, Elvis Presley's estate, and the Lorraine Motel, the site of Dr. Martin Luther King, Jr.'s assassination. The city is also well known for its cultivation of blues music. For more information on Memphis's history and symbolic importance, see History of Memphis, CITY OF MEMPHIS, http://www.cityofmemphis.org/framework.aspx?page=296 (last visited Oct. 19, 2012).

${ }^{221}$ See U.S. OfFICE OF MGMT. \& BUdGET, supra note 79.

222792 S.W.2d 446 (Tenn. 1990).

${ }^{223}$ See TenN. CODE ANN. § 6-51-103(a)(1)(A) (2011) (“Any aggrieved owner of property that borders or lies within territory that is the subject of an annexation ordinance prior to the operative date thereof, may file a suit in the nature of a quo warranto proceeding in accordance with this part, § 6-51-301 and title 29 , chapter 35 to contest the validity thereof on the ground that it reasonably may not be deemed necessary for the welfare of the residents and property owners of the affected territory and the municipality as a whole and so constitutes an exercise of power not conferred by law."); see also Vollmer, 792 S.W.2d at 449.

${ }^{224}$ See Vollmer, 792 S.W.2d at 447.

${ }^{225}$ See id. at 449. 
citizens of the entire region. ${ }^{226}$ The court concluded its reasonableness analysis by stating that its concern for the health, safety, and welfare of the citizens and property owners of the area also included the citizens and property owners residing in the city of Memphis. ${ }^{227}$

While the court in Byram II considered many of the same factors in evaluating the City of Jackson's attempted annexation of the Byram area, it was constrained by a very thin annexation regime and common-law lineage which lacked any meaningful consideration of the impact of boundary reformations on regional prosperity. Tennessee's annexation statute codifies the importance of annexation as urban policy in the plain language of the statute and creates parity between safeguards for citizens and municipalities. While Tennessee's annexation regime is fairly open to interpretation by the courts, the courts themselves have adopted common-law standards that afford considerable deference to the express language in the enabling statutes.

\section{North Carolina}

North Carolina's annexation regime has historically been hailed by many as a model urban policy that has contributed to the growth and economic development of its municipalities during the second half of the twentieth century. ${ }^{228}$ It is possible to connect the economic viability and attractiveness of North Carolina's several dynamic metropolitan regions with its annexation law. ${ }^{229}$ The state's annexation statute has its roots in the Municipal Government Study Commission, which was formed in 1958 in response to the concerns of the state's leading municipalities. The Commission's initial report declared that the periodic extension of municipal boundaries was essential for strong municipalities and the delivery of public services. ${ }^{230}$ The Commission declared that "cities cannot continue to remain strong and provide essential municipal services for sound development unless their

\footnotetext{
${ }^{226}$ See id.

${ }^{227}$ See id.

${ }^{228}$ See, e.g., RUSK, supra note 15; Rob Christensen, Many Hail North Carolina Annexation Law, NEwSOBSERVER.COM (Mar. 27, 2011), http://www.newsobserver.com/2011/03/27/1085023/many-hailncs-annexation-law.html.

${ }^{229}$ See Connolly, supra note 16 , at 82-83.

${ }^{230}$ See id. at 81 .
} 
U N I V E R S I T Y O F P I T T S B U R G H L A W R E V I E W

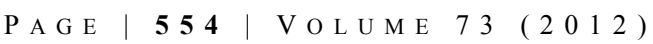

boundaries are periodically extended to take in those areas which require municipal services for sound development.",231

North Carolina's annexation statute contains two "Declaration of Policy" statements which communicate the values undergirding the state's approach to municipal annexation for communities above and below the 5,000 population mark. ${ }^{232}$ The declaration specifically addresses metropolitan sprawl by plainly stating that sound urban development is essential to the continued economic development of North Carolina. ${ }^{233}$ For the state's smaller municipalities, the statute states,

[N]ew urban development in and around municipalities having a population of less than 5,000 persons tends to be concentrated close to the municipal boundary rather than being scattered and dispersed as in the vicinity of larger municipalities, so that the legislative standards governing annexation by smaller municipalities can be simpler than those for larger municipalities . . . ${ }^{234}$

For the state's larger municipalities, the statute states,

$[\mathrm{N}]$ ew urban development in and around municipalities having a population of 5,000 or more persons is more scattered than in and around smaller municipalities, and that such larger municipalities have a greater difficulty in expanding municipal utility systems and other service facilities to serve such scattered development, so that the legislative standards governing annexation by larger municipalities must take these facts into account if the objectives set forth in this section are to be obtained. ${ }^{235}$

The statute's careful classification of small towns and large or growing municipalities exhibits a more nuanced understanding of the relationship between boundary expansion and urban development than that of Mississippi or Tennessee.

\footnotetext{
${ }^{231}$ See id. (citing Report of Municipal Government Study Commission (1958), reprinted in SELECTED MATERIALS ON MuniCiPAl ANNEXATION 41 (Jake Wicker ed., 1980)).

${ }^{232}$ See N.C. GEN. STAT. $§ 160 A-33,160 \mathrm{~A}-45$ (2011).

${ }^{233}$ See id. § 160A-45(1).

${ }^{234} I d . \S 160 \mathrm{~A}-33(4)$.

${ }^{235} I d$. § 160A-45(4).
} 
North Carolina's statute gives broad authority to municipalities to extend their corporate limits to include contiguous and non-contiguous areas provided they are capable of providing public services to the annexed area in substantially the same manner as they are provided to the rest of the municipality. ${ }^{236}$ Previously, the statute specifically focused on the annexation of areas developed for "urban purposes." 237 Areas developed for "urban purposes" were defined according to specific characteristics such as density, spatial ordering, and intensity of subdivision, land use, and infrastructure support. North Carolina courts have held that for proposed annexations, the test for compliance is whether the proposed annexation "substantially complies" with the statute; literal compliance is not required. $^{238}$

Up and until the changes enacted in the 2012 legislative session, North Carolina provided for both voluntary and involuntary annexations. ${ }^{239}$ The state's involuntary annexation provisions are credited for the policy's success but also ignited a significant backlash. ${ }^{240}$ Involuntary annexation was only afforded to municipalities with more than 5000 residents. ${ }^{241}$ North Carolina courts adjudicating involuntary annexation disputes have long emphasized that in an involuntary annexation, municipal services must be extended to annexed areas in a

${ }^{236}$ See id. § 160A-46; Davidson Cnty. v. High Point, 362 S.E.2d 553, 558 (N.C. 1987) (“A city, on the other hand, has statutory authority to annex areas both contiguous and noncontiguous to its primary corporate limits. It must stand ready to provide sewer service (among other services) to newly annexed areas on substantially the same basis and in the same manner in which these services are provided to the rest of the city.").

${ }^{237}$ See N.C. GEN. STAT. § 160A-48(c) (2010).

${ }^{238}$ See Briggs v. City of Asheville, 583 S.E.2d 733, 735 (N.C. Ct. App. 2003) (citing In re New Bern, 180 S.E.2d 851, $856(1971))$.

${ }^{239}$ See An Act to Require a Vote of the Residents Prior to the Adoption of an Annexation Ordinance Initiated by a Municipality, H.B. 925, 2011 N.C. SESS. LAws 2012-11; Gary D. Robertson, NC Governor Won't Block Forced Annexation Changes, S.F. Chron., June 10, 2012, available at $\mathrm{http} / / /$ www.sfgate.com/news/article/NC-governor-won-t-block-forced-annexation-changes3623182.php.

${ }^{240}$ Voluntary annexations are initiated by the petition of the landowners requesting that their land be annexed into a municipality. See N.C. GEN. STAT. § 160A-31(a) (2011) ("The governing board of any municipality may annex by ordinance any area contiguous to its boundaries upon presentation to the governing board of a petition signed by the owners of all the real property located within such area. The petition shall be signed by each owner of real property in the area and shall contain the address of each such owner.").

${ }^{241}$ See id. $\S 160$ A-46 ("The governing board of any municipality having a population of 5,000 or more persons according to the last federal decennial census may extend the corporate limits of such municipality under the procedure set forth in this Part.”). 
U N I V E R S I T Y O F P I T T S B U R G H L A W R E V I E W

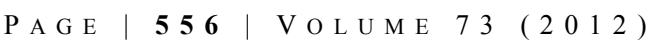

nondiscriminatory manner, meaning that annexed residents and property owners must receive substantially the same services that existing municipal residents and property owners receive. $^{242}$

Involuntary annexations were always required to satisfy specific requirements to prevent against arbitrariness annexations. ${ }^{243}$ The state's careful consideration of granting municipalities unilateral power was evident in its urban-use-andsubdivision test - an essential component of its former involuntary annexation provisions. The requirements stated that sixty percent of the property proposed for an involuntary annexation "must be developed for urban purposes."244 It allowed non-urban land to be annexed as well, provided that it (1) laid between the municipal boundary and an area developed for urban purposes so that the area developed for urban purposes is either not adjacent to the municipal boundary or cannot be served by the municipality without extending services through a sparsely developed area, or (2) was adjacent, on at least sixty percent of its external boundary, to any combination of the municipal boundary and the boundary of an area or areas developed for urban purposes. ${ }^{245}$

While North Carolina is generally comprised of small cities and townswhere most annexations occur - it has several mid-size regions. The Charlotte and Raleigh MSAs exceed one million in population, but neither exceeds two million. ${ }^{246}$ Neither of these areas has seen the level of annexation litigation that the Asheville MSA has. Over the past fifteen years, at least seven cases involving disputes over involuntary annexation proceedings have been litigated in North Carolina courts, and of these cases, only one involved a city other than Asheville. $^{247}$

${ }^{242}$ See Nolan v. Vill. of Marvin, 624 S.E.2d 305, 306 (N.C. 2006) (citing Greene v. Town of Valdese, 291 S.E.2d 630, 635 (1982)).

${ }^{243}$ See Connolly, supra note 16 , at 82.

${ }^{244}$ N.C. GEN. STAT. § 160A-48(c) (2011).

${ }^{245} I d . \S 160 \mathrm{~A}-48(\mathrm{c})(3)$.

${ }^{246}$ See U.S. OfFice OF MGMT. \& Budget, supra note 79.

${ }^{247}$ See generally Asheville Indus. v. City of Asheville, 436 S.E.2d 873 (N.C. Ct. App. 1993); Briggs v. City of Asheville, 583 S.E.2d 733 (N.C. Ct. App. 2003); Ridgefield Props. v. City of Asheville, 583 S.E.2d 400 (N.C. Ct. App. 2003); Carolina Power \& Light Co. v. City of Asheville, 597 S.E.2d 717 (N.C. 2004); Brown v. City of Winston-Salem; 626 S.E.2d 747 (N.C. Ct. App. 2006); Arnold v. City of Asheville, 610 S.E.2d 280 (N.C. Ct. App. 2005); Hall v. City of Asheville, 664 S.E.2d 77 (N.C. Ct. App. 2008). 
The Asheville MSA ranks 117 with a 2010 population of 424,858 and grew more than fifteen percent between the 2000 and 2010 census. ${ }^{248}$ Asheville's tax base grew $3.5 \%$ during the last quarter of 2009 , which was credited mostly to annexations. ${ }^{249}$ Carolina Light \& Power Co. v. City of Asheville ${ }^{250}$ illustrates how the state statute's guiding intent plays out in annexation challenges. The case involved a dispute over whether lands lying between the municipality and the urbanized areas sought for development fell within the exception for annexing unurbanized lands articulated in the statute. ${ }^{251}$

In explaining its reasoning, the court found that the legislative intent of the statute was to allow municipalities the opportunity to extend their services to reach urban core areas without being thwarted by intervening undeveloped land. ${ }^{252}$ Involuntary annexation and the urban-use-and-subdivision test operationalized this intent. They ensured that central cities were able to quickly respond to growth patterns in a manner that protects their ability to maximize their quality of life and economic development prospects, with the recognition that as these factors improve for the central city, the entire metropolitan region benefits.

North Carolina's annexation statute specifically limits the scope of judicial review in annexation cases. State courts have acknowledged judicial review as being restricted to addressing whether the municipality followed statutory procedures and, if not, whether those in the annexed area will suffer material injury, and whether the annexed area meets statutory requirements. ${ }^{253}$ In spite of this, some courts have gone beyond addressing procedural disputes and ventured into interpreting statutory provisions. ${ }^{254}$

${ }^{248}$ See U.S. OfFice OF MGMT. \& Budget, supra note 79.

${ }^{249}$ See David Forbes, Asheville City Council Considers Budget, Annexation and Supporting Artists, MOUNTAIN XPRESS (Feb. 23, 2010), http://mountainx.com/article/27130/Asheville-City-Councilconsiders-budget-annexation-and-supporting-artists.

${ }^{250} 597$ S.E.2d 717 (N.C. 2004).

${ }^{251}$ See id. at 719.

${ }^{252}$ See id. at 724 (citing In re City of Albemarle, 266 S.E.2d 661, 663-64 (N.C. 1980)).

${ }^{253}$ See Ashley v. City of Lexington, 704 S.E.2d 529, 533-34 (N.C. App. Ct. 2011) (citing City of Kannapolis v. City of Concord, 391 S.E.2d 493, 496 (N.C. 1990)).

${ }^{254}$ See Nolan v. Marvin, 624 S.E.2d 305, 309 (N.C. 2006) (Edmunds, J., dissenting) (“Although we review the trial court's conclusions of law de novo, the majority appears to accept that the Village complied with the facial requirements of N.C.G.S. § 160A-35(3). The public policy set out in N.C.G.S. $\S 160 \mathrm{~A}-33$ and quoted by the majority requires no more than that the area to be annexed receive the same services as are provided within the annexing municipality. Nevertheless, the majority now relies 
North Carolina's involuntary annexation statutory provisions have caused considerable controversy, specifically because they are the most pro-municipality of such provisions among states that allow for involuntary annexation. ${ }^{255}$ After years of political battles over involuntary annexation, on June 18, 2011, the North Carolina legislature ratified House Bill 845, entitled "An Act to Reform the Involuntary Annexation Laws of North Carolina." 256 The legislation weakened the state's annexation regime by allowing a majority of property owners in an annexed area to deliver a petition to the municipality's governing board challenging the annexation. Additional changes followed in the 2012 legislative session. North Carolina House Bill 925 became law when the Governor refused to sign or veto the measure after the session. ${ }^{257}$ The legislation changed the annexation process to a referendum vote of the annexation area, effectively ending involuntary annexation in North Carolina.

These developments are the culmination of a protracted fight to end involuntary annexation. The communities fighting involuntary annexation were wealthy, predominately white communities comprised of individuals who fled the central cities to live on their close-in periphery. ${ }^{258}$ While there are certainly a range

on N.C.G.S. $§ 160 \mathrm{~A}-33$ to add a gloss to N.C.G.S. $\S 160 \mathrm{~A}-35(3)$ to require that the annexing municipality provide public services that exceed to a 'meaningful' degree the services the area to be annexed is already receiving.").

${ }^{255}$ Compare, e.g., N.C. GEN. STAT. § 160A-48(c)(3) (2011) (allowing municipalities broad involuntary annexation authority for urbanized areas), with IDAHO CODE ANN. §50-222(1), (3)(a)(iii) (2011) (allowing for involuntary annexation for lands that are residential and less than one hundred privatelyowned parcels, which are surrounded on all sides by land within a city), and KAN. STAT. ANN. $§ 12-$ 520a (2011) (allowing for involuntary annexation upon the consideration of sixteen specific factors).

${ }^{256}$ An Act to Reform the Involuntary Annexation Laws of North Carolina, 2011 N.C. Sess. Laws 396 (H.B. 845).

${ }^{257}$ See An Act to Require a Vote of the Residents Prior to the Adoption of an Annexation Ordinance Initiated by a Municipality, H.B. 925, 2011 N.C. SESS. LAWS 2012-11; Robertson, supra note 239.

${ }^{258}$ For instance, the Biltmore Lake Community Action Committee, a neighborhood group formed around a community located on the outskirts of Asheville, North Carolina, organized and raised more than $\$ 100,000$ to cover the legal costs associated with stopping an annexation by the city of Asheville. In 2007, the Asheville city council voted to annex about 440 acres in the upscale Biltmore community. The annexation would have added 768 residents and $\$ 1.2$ million in tax revenue for Asheville. The annexation never took effect, because Biltmore residents have challenged it in court. Residents of the Biltmore Lake community began a petition effort to block an annexation by Asheville. The residents in the Gates Four community near Fayetteville, North Carolina began the same process. The community of about 650 residents has battled for several years against the attempted annexation, which was part of a major city expansion intended to add twenty-seven square miles and 42,000 people to the city at once. See Around the Region: N.C. Residents Use New Law to Block Annexations, TrYON DAILY BULLETIN (June 24, 2011), www.tryondailybulletin.com/2011/06/24/around-the-region-n-c-residents-use-new-lawto-block-annexations/. 
of motivations for relocating, the previously referenced history of metropolitan settlement patterns suggest that race and class likely played a role in motivating those in staunch opposition to involuntary annexation in North Carolina. ${ }^{259}$ The backlash provides yet another window into the race and class dynamics associated with the social construction of boundaries.

It is important to note that race and class-based criticisms do not always cut in favor of involuntary annexation. Some argue that involuntary annexation results in bottom-line approaches that favor the annexation of wealthy areas while overlooking poorer areas where the cost to extend municipal services would exceed the amount of tax revenues received. ${ }^{260}$ While "cherry-picking" annexation should be restricted, it should not be used in a fashion that undermines the involuntary annexation regime entirely. By allowing municipalities to recapture wealthy outmigration, it serves a redistributive function that ultimately benefits poorer residents.

North Carolina's metropolitan regions have grown and experienced economic development success during the period since the enactment of its progressive annexation regime. Between 1960 and 2010, the Raleigh MSA saw its population more than triple. Neighboring state capitals, however, did not see similar growth. Columbia, South Carolina, had a slight increase, while Richmond, Virginia, shrank. Those cities are significantly smaller than Raleigh, and their residents are poorer, based on personal income data. ${ }^{261}$ Additionally, Raleigh, Cary, Durham, Chapel Hill, Greensboro, High Point, Winston-Salem, and Charlotte have all earned the highest AAA bond ratings. ${ }^{262}$

\section{Annexation Lessons}

Involuntary annexation is what made North Carolina's annexation regime a model for the nation. Tennessee benefits from a comprehensive urban growth boundary approach that privileges central cities in the annexation process. Both

\footnotetext{
${ }^{259}$ See supra note 57 and accompanying text.

${ }^{260}$ See Connolly, supra note 16, at 85-95 (discussing the communities of Southern Moore County and the disparities between the affluent predominately white areas that have been annexed by the municipalities of Aberdeen, Southern Pines, and Pinehurst, and the predominately black communities that comprise the unincorporated areas of the county).

${ }^{261}$ See Christensen, supra note 228.

${ }^{262}$ See Moody's Credit Perspective: Public Finance, MoOdy's InVESTOR SERviCes (Oct. 22, 2002), http://www.moodys.com/research/Moodys-Credit-Perspectives-Public-Finance--PBM_PBM76374 (paid subscription required to access).
} 
U N I V E R S I T Y O F P I T T S B U R G H L A W R E V I E W

PAGE

states have better performing mid-size metropolitan regions than Mississippi, which lacks any comparable urban growth policy.

State annexation regimes should include preferential treatment for mid-size central cities that risk being landlocked due to municipal incorporations on their peripheries. Such qualifications should take into consideration the metropolitan region's population and demographic distribution, a relative assessment of the suburban incorporation threat in the region, the degree of social stratification, and how central city boundary expansion would meaningfully and measurably alter the economic development prospects for the metropolitan region.

The effects of metropolitanization and its redefinition of the metropolis suggest that metropolitan residents may not be concerned with the municipal subunit within which they reside. Therefore, annexation policy should seek to sever residential and political identities by reconstructing the legal geography of the metropolis. ${ }^{263}$ This has the potential to resolve both the external challenges of attracting economic development opportunities with the internal challenges of reducing social stratification.

In addition to allowing for features such as involuntary annexation, a procentral city annexation regime must include clear, unambiguous policy positions on annexation as urban policy. Of the three, only Tennessee and North Carolina avow annexation's role in ensuring prosperity, sound urban development, and curbing the effects of urban sprawl. Mississippi's lack of an express urban policy focus in its annexation regime renders it at a significant disadvantage to its regional neighbors.

\section{CONCLUSION}

None of the challenges facing the modern American metropolis can be addressed on a municipality-by-municipality basis. Mid-size metropolitan regions are more acutely affected by increased intra-regional fragmentation and the corresponding lack of intra-regional economic development cooperation it can produce. In order to be competitive, metropolitan regions must leverage their strengths, maximize their economies of scale, and merge their assets into a unified regional economic and political unit. Therefore, the central cities of mid-size regions need annexation regimes that prioritize the elasticity of their boundaries and allow them to thwart fragmentation and the challenges it poses for the region's competitiveness.

\footnotetext{
${ }^{263}$ See Richard Thompson Ford, Beyond Borders: A Partial Response to Richard Briffault, 48 STAN. L.
} REV. 1173, 1185-86 (1996). 
A N N E X A T I O N A N D T H E M I D-S I Z E M E T R O P O L I S

\begin{tabular}{l|lll} 
P A G E & 561
\end{tabular}

Annexation is certainly not a cure-all for the challenges facing mid-size regions. To the extent that a range of approaches is needed, annexation can be used as a short-term stopgap that will allow mid-size central cities the ability to stabilize their tax bases while making longer-term investments in creating meaningful, more robust regional governance structures. 